\title{
New Uranyl Open Framework and Sheet Compounds Formed via In-Situ Protonation of Piperazine by Phosphorous Acid
}

\author{
Eric M. Villa ${ }^{1,2, *,+}$, Justin N. Cross ${ }^{1,2, \pm(1)}$ and Thomas E. Albrecht-Schmitt ${ }^{1,2, \S}$ \\ 1 Department of Civil Engineering and Geological Sciences, University of Notre Dame, 156 Fitzpatrick Hall, \\ Notre Dame, IN 46556, USA; jncross@lanl.gov (J.N.C.); albrecht-schmitt@chem.fsu.edu (T.E.A.-S.) \\ 2 Department of Chemistry and Biochemistry, University of Notre Dame, Notre Dame, IN 46556, USA \\ * Correspondence: EricVilla@Creighton.edu \\ + Current address: Department of Chemistry, Creighton University, 2500 California Plaza, \\ Omaha, NB 68178, USA. \\ $\ddagger$ Current address: Los Alamos National Laboratory, Los Alamos, NM 87545, USA. \\ $\S$ Current address: Department of Chemistry and Biochemistry, Florida State University, 95 Chieftain Way, \\ Tallahassee, FL 32306, USA.
}

Received: 12 September 2018; Accepted: 19 October 2018; Published: 1 November 2018

check for updates

\begin{abstract}
Two new uranyl compounds were hydrothermally synthesized employing piperazine as an organic templating agent. The piperazine was protonated in-situ by phosphorous acid, forming the piperazinium dication featured in these compounds. The two new structures presented here are a uranyl phosphite 2D sheet and a 3D uranyl mixed phosphite-phosphate network with cation occupied channels. Both included strong hydrogen bonding from the piperazinium cation to the uranyl phosphite or mixed phosphite-phosphate network. These two structures can be reliably formed through careful control of $\mathrm{pH}$ of the starting solution and the reaction duration. The piperazinium uranyl phosphite compound was the latest in a family of uranyl phosphites, and demonstrates the structural versatility of this combination. The mixed phosphite-phosphate compound builds on hydrothermal redox chemistry, illustrating the variety of compounds that can be isolated by exploiting in-situ redox processes to elucidate new uranium structure types.
\end{abstract}

Keywords: uranium(VI); phosphite; piperazinium; hydrothermal redox; crystal structures

\section{Introduction}

Nuclear waste associated with energy production poses potential long-term hazards due to the vast quantities of nuclear material used in the industry. Actinide phosphates or phosphate additives have gained interest as potential storage forms to diminish the transport of actinides in the environment, owing to their generally low solubility [1-5]. Limiting the mobility of uranium in the environment is important with regards to waste storage in a geologic repository to diminish environmental impact. In addition to using ligands that generate low solubilities, such as phosphate, another method for limiting the solubility and subsequent transport of uranium is reducing the oxidation state of uranium from the ubiquitous $\mathrm{U}(\mathrm{VI})$ to generally less soluble $\mathrm{U}(\mathrm{IV})$.

The phosphite anion, $\mathrm{HPO}_{3}{ }^{2-}$, has a tetrahedral geometry with the phosphorus atom bound by three oxygen atoms and one hydrogen atom. Here the central phosphorus atom is in a lower P(III) oxidation state, compared to the typical $\mathrm{P}(\mathrm{V})$ observed in phosphate, and allows for potentially useful redox chemistry to occur. Phosphite has $3 m$ (or $\mathrm{C}_{3 v}$ ) point group symmetry and is a fairly strong 
reducing agent. At both low Equation (1) and high Equation (2) $\mathrm{pH}$, it is thermodynamically favorable for phosphite to oxidize to phosphate:

$$
\begin{aligned}
& \mathrm{H}_{3} \mathrm{PO}_{3}+\mathrm{H}_{2} \mathrm{O} \rightleftharpoons \mathrm{H}_{3} \mathrm{PO}_{4}+2 \mathrm{H}^{+}+2 \mathrm{e}^{-} \mathrm{E}^{\circ}=+0.276 \mathrm{~V}, \\
& \mathrm{HPO}_{3}^{2-}+3 \mathrm{OH}^{-} \rightleftharpoons \mathrm{PO}_{4}^{3-}+2 \mathrm{H}_{2} \mathrm{O}+2 \mathrm{e}^{-} \mathrm{E}^{\circ}=+1.05 \mathrm{~V},
\end{aligned}
$$

These favorable oxidation pathways can assist in not only reducing different actinides, but also in helping to stabilize their lower oxidation states, effectively acting as a holding agent, which limits solubility and transport as mentioned previously. Phosphite and its corresponding acid, phosphorous acid, can be used as precursors to making phosphonates, which has provided many different families of actinide phosphonates and sees utility as a functional group for ion exchange resins [6-13].

Our early work in actinide phosphites focused on simple actinide(III) and actinide(IV) phosphites structures, demonstrating the actinide contraction and the influence of the starting oxidation state of the actinide on product composition $[14,15]$. Here the phosphite anion stabilized the lower oxidation states of uranium, neptunium, and plutonium with an eye towards potential waste storage media and the exploration of periodic trends. From here, we expanded to study the in-situ redox chemistry that occurs within different uranium-phosphite systems by varying reaction times and $\mathrm{pHs}$ to isolate compounds with various oxidation states of $U$ and $P$ [16-18]. In these studies, uranyl phosphite compounds were formed at short reaction times (a few hours) with the addition of carbonate salts. As the reaction time was extended, mixed valent $\mathrm{U}(\mathrm{IV})-\mathrm{U}(\mathrm{VI})$-phosphite-phosphate compounds were isolated. Lastly, by extending the reaction to several days, completely redox reacted U(IV)-phosphates could be isolated. In all cases, the starting $\mathrm{pH}$ and reaction duration were key in the formation of these new products. Previous to the work mentioned above, some initial studies on the isolation of uranium phosphites had been reported [19-22]. Other notable studies of actinide phosphites have been accomplished, such as synthesis with a phosphorous acid melt [23], the isolation of a heterometallic phosphite compound [24], and phosphites templated with organic molecules [25-27]. Recently, a unique purple U(IV) phosphite compound was synthesized solvothermally utilizing the even stronger reducing power of hypophosphorous acid [28].

The coordination chemistry of $\mathrm{U}(\mathrm{IV})$ and $\mathrm{U}(\mathrm{VI})$ differ greatly and are described in detail in several excellent reviews [29-35]; a brief description is given in this study. Uranium(IV) is commonly an eight or nine-coordinate, although its coordination numbers can vary from six to twelve, and the distribution of ligands in its coordination sphere is largely isotropic. On the other hand, uranium(VI) in the presence of oxygen typically has two strongly bonded oxygen atoms, which gives rise to the linear uranyl cation, $\mathrm{UO}_{2}{ }^{2+}$. Here the coordination environment is generally limited to tetragonal, pentagonal, or hexagonal bipyramids, and its geometries are highly anisotropic because of the short, terminal oxo atoms. These fundamental differences lead to divergent extended structures, with U(IV) usually yielding 3D networks, whilst $\mathrm{U}(\mathrm{VI})$ is most often found in 2D sheets or 1D chains.

Here we look to use the reducing power of phosphite to create unique uranium geometric systems and expand on the previous uranium-phosphite work by utilizing piperazine as a templating agent. As previously observed, the major influences on the products formed are the starting $\mathrm{pH}$ and reaction time. The subtle interplay between $\mathrm{pH}$, reaction time, and temperature lead to the oxidation of phosphite to phosphate; however, parsing the primary driving force for these reactions will likely remain difficult without real-time in situ analysis. The two new compounds described here illustrate the interesting networks that can be obtained when carefully controlling the oxidation state of the oxoanions present. 


\section{Materials and Methods}

Caution, while the $\mathrm{UO}_{2}\left(\mathrm{NO}_{3}\right)_{2} \cdot 6 \mathrm{H}_{2} \mathrm{O}$ used in this study contained depleted uranium, standard precautions for handling radioactive materials, such as uranyl nitrate, should be followed.

Syntheses. Uranyl nitrate, $\mathrm{UO}_{2}\left(\mathrm{NO}_{3}\right)_{2} \cdot 6 \mathrm{H}_{2} \mathrm{O}$, (International Bio-analytical Industries, Inc., Boca Raton, FL, USA), cesium carbonate, $\mathrm{Cs}_{2} \mathrm{CO}_{3}$, (Alfa-Aesar, 99.9\%), piperazine, $\mathrm{C}_{4} \mathrm{H}_{10} \mathrm{~N}_{2}$, (Alfa-Aesar, 99\%), and phosphorous acid, $\mathrm{H}_{3} \mathrm{PO}_{3}$, (Alfa-Aesar, 97\%) were used as received. All hydrothermal reactions were conducted in the same manner, unless otherwise listed. The reactants were mixed in their appropriate ratios and loaded into a $23 \mathrm{~mL}$ PTFE autoclave liner with $2 \mathrm{~mL}$ of distilled water. The liner was then sealed in a stainless-steel autoclave and placed into a box furnace. The furnace was then ramped up to the desired temperature for the stated number of hours and then slowly cooled at a rate of $7.5{ }^{\circ} \mathrm{C}$ per hour. Reactions were then washed with cold water to remove non-crystalline material. The products were then placed into a petri dish and dispersed with ethanol for easier separation. The reaction conditions listed below represent the amounts and reaction times for the specific crystals obtained for single crystal diffraction. The concentration of phosphorous acid was found to be quite important, as concentrations below $1.00 \mathrm{M} \mathrm{H}_{3} \mathrm{PO}_{3}$ yielded simple phosphate phases, which will not be discussed in this manuscript. Herein, piperazine is abbreviated as PZ and $\mathrm{H}_{2} \mathrm{PZ}$ will be used for the doubly protonated $\mathrm{H}_{2} \mathrm{C}_{4} \mathrm{H}_{10} \mathrm{~N}^{2+}$.

$\left(\mathrm{H}_{2} \mathbf{P Z}\right)\left[\mathrm{UO}_{2}\left(\mathrm{HPO}_{3}\right)_{2}\right]$. This compound was synthesized by loading $99.5 \mathrm{mg}$ uranyl nitrate (99.1 mM), $393.0 \mathrm{mg} \mathrm{Cs} 2 \mathrm{CO}_{3}(603 \mathrm{mM})$, and $90.0 \mathrm{mg}$ piperazine (PZ; $\left.1.07 \mathrm{M}\right)$ into a $23 \mathrm{~mL}$ PTFE autoclave liner with $2 \mathrm{~mL}$ of a $2.00 \mathrm{M}$ aqueous solution of $\mathrm{H}_{3} \mathrm{PO}_{3}$. This yielded an approximate ratio of reactants of $10 \mathrm{PZ}: 6 \mathrm{Cs}_{2} \mathrm{CO}_{3}$ : $\mathrm{U}(\mathrm{VI}): 20 \mathrm{H}_{3} \mathrm{PO}_{3}$. The liner was then sealed in a stainless-steel autoclave, placed into a box furnace, heated to $175^{\circ} \mathrm{C}$ over a 30-min period, held at temperature for $2 \mathrm{~h}$, and finally cooled at a rate of $7.5^{\circ} \mathrm{C}$ per hour. Several light-yellow prisms suitable for crystallographic studies of the formula stated above were isolated. $\left(\mathrm{H}_{2} \mathrm{PZ}\right)\left[\mathrm{UO}_{2}\left(\mathrm{HPO}_{3}\right)_{2}\right]$ was the only single-crystalline product observed in the reaction vessel, and approximate yields ranged between $60-80 \%$ based on the mass of uranium based on visual inspection. The concentration of cesium carbonate could be lowered and the above phase was the only single crystal phase obtained from the reaction; however, this ratio yielded the highest quality crystals.

$\left[\left(\mathbf{H}_{2} \mathbf{P Z}\right) \mathrm{Cs}\right]\left[\left(\mathrm{UO}_{2}\right)_{2}\left(\mathrm{HPO}_{3}\right)_{2}\left(\mathbf{P O}_{4}\right)\right]$. This mixed phosphite-phosphate was synthesized at nearly the same conditions as the above compound, but with an increase in time and temperature of the reaction. Then, $100.2 \mathrm{mg}$ uranyl nitrate $(99.8 \mathrm{mM}), 392.1 \mathrm{mg} \mathrm{Cs}{ }_{2} \mathrm{CO}_{3}(602 \mathrm{mM})$, and $90.0 \mathrm{mg}$ piperazine (PZ; $1.07 \mathrm{M}$ ) was loaded into a $23 \mathrm{~mL}$ PTFE autoclave liner with $2 \mathrm{~mL}$ of a $2.00 \mathrm{M}$ aqueous solution of $\mathrm{H}_{3} \mathrm{PO}_{3}$. This yielded an approximate ratio of reactants of $10 \mathrm{PZ}: 6 \mathrm{Cs}_{2} \mathrm{CO}_{3}: \mathrm{U}(\mathrm{VI}): 20 \mathrm{H}_{3} \mathrm{PO}_{3}$. The liner was then sealed in a stainless-steel autoclave, placed into a box furnace, heated to $20{ }^{\circ} \mathrm{C}$ over a 30-min period, held at temperature for $6 \mathrm{~h}$, and finally cooled at a rate of $7.5^{\circ} \mathrm{C}$ per hour. Several light-yellow prisms suitable for crystallographic studies of the formula above were isolated. Approximate yields for $\left[\left(\mathrm{H}_{2} \mathrm{PZ}\right) \mathrm{Cs}\right]\left[\left(\mathrm{UO}_{2}\right)_{2}\left(\mathrm{HPO}_{3}\right)_{2}\left(\mathrm{PO}_{4}\right)\right]$ ranged between $60-80 \%$ based on the mass of uranium, as this was the only single-crystalline product observed in the vessel this was done via visual inspection. It should be noted that this product was also found at lower cesium carbonate concentrations, but, like above, this ratio yielded the best crystals for single-crystal investigations. This product was also found at these same reactant concentrations at only $2 \mathrm{~h}$ of reaction, but the yield was much lower.

Crystallographic Studies. Each crystal of the above compounds was mounted on MiTeGen Microloop with non-drying immersion oil, and optically aligned on a Bruker APEXII Quazar X-ray diffractometer using a digital camera. Initial intensity measurements were performed using a I $\mathrm{S}$ X-ray source, a $30 \mathrm{~W}$ microfocused sealed tube $(\mathrm{MoK} \alpha, \lambda=0.71073 \AA)$ with high-brilliance and high-performance focusing Quazar multilayer optics. Standard APEXII software was used for determination of the unit cells and data collection control. The intensities of reflections of a sphere were collected by a combination of an appropriate number of exposures (frames). Each set had a different $\varphi$ angle for the crystal and each exposure covered a range of $0.5^{\circ}$ in $\omega$. SAINT software was used for 
data integration including Lorentz and polarization corrections. The structure was initially solved using SHELXT Intrinsic Phasing and refined using SHELXL [36,37]. Olex2 was used as a graphical interface [38]. The different renderings of the above compounds were made using CrystalMaker ${ }^{\circledR}$ for Windows, version 9.2.9.48, as described in Reference [39]. Crystallographic information for all obtained phases is summarized in Table 1. Atom coordinates and their displacement parameters are listed in Tables 2 and 3, with selected bond lengths shown in Table 4. Selected hydrogen bonding information from the piperazinium dication to the anion network is shown in Table 5. Additional structural information were provided in the Supplementary Materials (CIF's). Note: The refinement of Compound 2 has some higher than expected refinement values in $w \mathrm{R}, \mathrm{S}$, and residual peaks due to minor twinning and minor disorder of the phosphite ligand groups, neither of which could be cleanly modelled in structure refinement.

UV-vis-NIR Spectroscopy. UV-vis-NIR data were acquired from single crystals using a Craic Technologies microspectrophotometer. Crystals were placed on quartz slides under Krytox oil, and the data were collected at 200 to $1400 \mathrm{~nm}$. The exposure time was auto optimized by the Craic software. The characteristic peaks for the $\mathrm{U}^{6+}$ are listed with the acquired spectra and pictures of the crystals are shown in Appendix A (see Figure A1), as in References [40,41].

Table 1. Table of crystallographic data for listed compounds: $\left[\mathrm{H}_{2} \mathrm{PZ}\right]\left[\mathrm{UO}_{2}\left(\mathrm{HPO}_{3}\right)_{2}\right](1)$ and $\left[\left(\mathrm{H}_{2} \mathrm{PZ}\right) \mathrm{Cs}\right]\left[\left(\mathrm{UO}_{2}\right)_{2}\left(\mathrm{HPO}_{3}\right)_{2}\left(\mathrm{PO}_{4}\right)\right](2)$.

\begin{tabular}{|c|c|c|}
\hline \multicolumn{3}{|c|}{ Compounds } \\
\hline $\begin{array}{c}\text { Chemical Formula } \\
M_{\mathrm{r}}(\mathrm{g} / \mathrm{mol})\end{array}$ & $\begin{array}{c}{\left[\mathrm{H}_{2} \mathrm{C}_{4} \mathrm{H}_{10} \mathrm{~N}_{2}\right]\left[\mathrm{UO}_{2}\left(\mathrm{HPO}_{3}\right)_{2}\right]} \\
518.14\end{array}$ & $\begin{array}{c}{\left[\left(\mathrm{H}_{2} \mathrm{C}_{4} \mathrm{H}_{10} \mathrm{~N}_{2}\right) \mathrm{Cs}\right]\left[\left(\mathrm{UO}_{2}\right)_{2}\left(\mathrm{HPO}_{3}\right)_{2}\left(\mathrm{PO}_{4}\right)\right]} \\
1016.05\end{array}$ \\
\hline Crystal System & Monoclinic & Monoclinic \\
\hline Space Group & $\mathrm{P} 2_{1} / n$ & $\mathrm{I} 2 / a$ \\
\hline$a, \AA$ & $8.3711(2)$ & $12.4927(3)$ \\
\hline$b, \AA$ & $7.2898(2)$ & $6.64030(10)$ \\
\hline$c, \AA$ & $10.8505(3)$ & $44.7504(9)$ \\
\hline$\beta$, deg. & $112.205(3)$ & $97.631(2)$ \\
\hline$V, \AA^{3}$ & 613.03(3) & $3679.40(13)$ \\
\hline Z & 2 & 8 \\
\hline Density $\left(\mathrm{g} / \mathrm{cm}^{3}\right)$ & 2.807 & 3.668 \\
\hline Absorption Coefficient $\left(\mathrm{mm}^{-1}\right)$ & 13.531 & 19.864 \\
\hline Crystal Size $\left(\mathrm{mm}^{3}\right)$ & $0.150 \times 0.099 \times 0.095$ & $0.153 \times 0.070 \times 0.028$ \\
\hline \multicolumn{3}{|c|}{ Data Collection } \\
\hline Temperature, $\mathrm{K}$ & 293(2) & 293(2) \\
\hline Radiation type, wavelength & \multicolumn{2}{|c|}{$\operatorname{MoK} \alpha(\lambda=0.71073)$} \\
\hline Absorption correction & \multicolumn{2}{|c|}{$\begin{array}{l}\text { CrysAlis PRO 1.171.39.44a Empirical absorption correction using spherical } \\
\text { harmonics, implemented in SCALE3 ABSPACK scaling algorithm }\end{array}$} \\
\hline $2 \theta$ angles range, deg. & 5.288 to 61.008 & 3.674 to 58.358 \\
\hline Reflections collected & 17323 & 20732 \\
\hline Unique reflections & 1870 & 4640 \\
\hline Observed reflections & 1676 & 4304 \\
\hline \multicolumn{3}{|c|}{ Structure Refinement } \\
\hline$R_{\text {int }}$ & 0.0302 & 0.0406 \\
\hline $\mathrm{R}_{1}\left[\mathrm{~F}^{2}>2 \sigma\left(\mathrm{F}^{2}\right)\right], w \mathrm{R}_{2}\left[\mathrm{~F}^{2}\right]$ & $\mathrm{R}_{1}=0.0139, w \mathrm{R}_{2}=0.0334$ & $\mathrm{R}_{1}=0.0473, w \mathrm{R}_{2}=0.1199$ \\
\hline $\mathrm{R}_{1}$ [all data], $w \mathrm{R}_{2}$ [all data] & $\mathrm{R}_{1}=0.0164, w \mathrm{R}_{2}=0.0347$ & $\mathrm{R}_{1}=0.0507, w \mathrm{R}_{2}=0.1216$ \\
\hline Data/Restraints/Parameters & $1870 / 0 / 83$ & $4640 / 2 / 243$ \\
\hline$S$ & 1.047 & 1.151 \\
\hline$\varrho_{\max }, \varrho_{\min }, \mathrm{e} \cdot \AA^{-3}$ & $0.99 /-0.78$ & $7.63 /-4.74$ \\
\hline
\end{tabular}

Note: Computer programs: CrysAlis PRO 1.171.38.46, [42] ShelXT, [36] SHELXL, [37] and Olex2 [38]. 
Table 2. Fractional Atomic Coordinates $\left(\times 10^{4}\right)$ and Equivalent Isotropic Displacement Parameters $\left(\AA^{2} \times 10^{3}\right)$ for both (1) and (2). $U_{\text {eq }}$ is defined as $1 / 3$ of the trace of the orthogonalized $U_{\text {IJ }}$ tensor.

\begin{tabular}{|c|c|c|c|c|}
\hline \multicolumn{5}{|c|}{ Compound (1) } \\
\hline Atom & $x$ & $\mathbf{y}$ & $\mathbf{z}$ & $\mathrm{U}(\mathrm{eq})$ \\
\hline U1 & 5000 & 10000 & 5000 & $14.05(5)$ \\
\hline P1 & $5888.3(7)$ & 6339.8(8) & 7398.3(5) & $16.95(10)$ \\
\hline O1 & $5967(2)$ & $7415(2)$ & $6212.5(17)$ & $27.0(4)$ \\
\hline $\mathrm{O} 2$ & $4379(2)$ & $6866(2)$ & 7754.3(17) & 25.2(3) \\
\hline O3 & $7610(2)$ & 6466(3) & 8567.0(18) & $32.9(4)$ \\
\hline $\mathrm{O} 4$ & $6152(2)$ & 9354(3) & 3979.2(17) & $26.4(3)$ \\
\hline N1 & 1300(3) & $5175(2)$ & $6311(2)$ & $19.6(4)$ \\
\hline $\mathrm{C} 1$ & 1738(3) & $4512(4)$ & $5178(2)$ & 23.2(4) \\
\hline $\mathrm{C} 2$ & $-208(3)$ & $6440(3)$ & $5841(2)$ & $24.8(5)$ \\
\hline \multicolumn{5}{|c|}{ Compound (2) } \\
\hline Atom & $x$ & $\mathbf{y}$ & $\mathbf{z}$ & $\mathrm{U}(\mathrm{eq})$ \\
\hline U1 & $4660.3(3)$ & $3993.4(6)$ & $6943.7(2)$ & $6.84(11)$ \\
\hline U2 & $3936.9(3)$ & $4145.2(6)$ & $5548.8(2)$ & $9.85(11)$ \\
\hline Cs1 & 2500 & -2500 & 7500 & $27.0(3)$ \\
\hline Cs2 & 2500 & 8845.0(19) & 5000 & $33.4(3)$ \\
\hline P1 & $5148(3)$ & $-1155(4)$ & 7234.0(7) & $12.0(5)$ \\
\hline P2 & $6160(2)$ & $6479(5)$ & $5252.7(7)$ & $16.1(6)$ \\
\hline P3 & $4155(2)$ & $3975(4)$ & $6249.3(6)$ & $8.2(5)$ \\
\hline O1 & 5331(7) & 789(12) & 7064.4(19) & 16.3(17) \\
\hline $\mathrm{O} 2$ & $4370(7)$ & $-2595(12)$ & 7054.0(18) & $12.4(15)$ \\
\hline O3 & $4778(7)$ & $-721(12)$ & 7539.1(18) & $12.5(15)$ \\
\hline $\mathrm{O} 4$ & $5626(7)$ & $5397(18)$ & $5490(2)$ & $27(2)$ \\
\hline O5 & $6220(7)$ & $5224(13)$ & 4970.7(19) & $14.8(16)$ \\
\hline O6 & $7263(7)$ & $7299(14)$ & $5386(2)$ & 18.0(17) \\
\hline O7 & 4991(7) & $4712(14)$ & $6053.9(18)$ & $14.5(16)$ \\
\hline O8 & 3194(7) & $3271(14)$ & 6017.5(18) & 16.1(17) \\
\hline O9 & $3819(7)$ & $5604(13)$ & 6466.2(19) & $16.9(17)$ \\
\hline $\mathrm{O} 10$ & $4610(7)$ & $2259(12)$ & 6461.6(18) & $14.3(16)$ \\
\hline $\mathrm{O} 11$ & $3330(7)$ & $3277(14)$ & $7014(2)$ & $16.6(17)$ \\
\hline $\mathrm{O} 12$ & $6005(6)$ & $4644(12)$ & $6884.5(18)$ & $12.5(15)$ \\
\hline O13 & $3383(8)$ & $6631(14)$ & $5573(2)$ & $22.5(19)$ \\
\hline $\mathrm{O} 14$ & $4457(7)$ & $1657(14)$ & 5508.1(19) & 19.4(18) \\
\hline N1 & 1040(10) & $260(20)$ & $5970(3)$ & $28(3)$ \\
\hline N2 & $2243(10)$ & $-244(18)$ & $6559(3)$ & $24(2)$ \\
\hline $\mathrm{C} 1$ & $1330(8)$ & 2017(17) & 6171(3) & $11(2)$ \\
\hline $\mathrm{C} 2$ & $1876(10)$ & $-1410(18)$ & 6033(3) & $16(2)$ \\
\hline $\mathrm{C} 3$ & 1962(9) & $-2011(17)$ & 6359(2) & $11(2)$ \\
\hline $\mathrm{C} 4$ & 1452(9) & 1431(19) & 6496(3) & $14(2)$ \\
\hline
\end{tabular}

Table 3. Anisotropic Displacement Parameters $\left(\AA^{2} \times 10^{3}\right)$ for both Compound (1) and (2). The Anisotropic displacement factor exponent takes the form: $-2 \pi^{2}\left[h^{2} a *{ }^{2} U_{11}+2 h k a * b * U_{12}+\ldots\right]$.

\begin{tabular}{ccccccc}
\hline \multicolumn{7}{c}{ Compound (1) } \\
\hline Atom & $\mathbf{U}_{\mathbf{1 1}}$ & $\mathbf{U}_{\mathbf{2 2}}$ & $\mathbf{U}_{\mathbf{3 3}}$ & $\mathbf{U}_{\mathbf{2 3}}$ & $\mathbf{U}_{\mathbf{1 3}}$ & $\mathbf{U}_{\mathbf{1 2}}$ \\
\hline $\mathrm{U} 1$ & $12.31(6)$ & $18.32(7)$ & $9.81(6)$ & $-0.24(3)$ & $2.26(4)$ & $1.18(3)$ \\
$\mathrm{P} 1$ & $15.2(2)$ & $17.2(2)$ & $15.8(2)$ & $1.7(2)$ & $2.79(18)$ & $1.7(2)$ \\
$\mathrm{O} 1$ & $30.3(9)$ & $28.8(8)$ & $24.5(8)$ & $10.5(7)$ & $13.5(7)$ & $10.0(7)$ \\
$\mathrm{O} 2$ & $21.7(8)$ & $29.4(8)$ & $26.5(8)$ & $-3.7(7)$ & $11.3(7)$ & $-1.8(6)$ \\
$\mathrm{O} 3$ & $22.3(8)$ & $34.3(10)$ & $28.5(9)$ & $3.7(8)$ & $-5.9(7)$ & $4.9(7)$ \\
$\mathrm{O} 4$ & $30.3(9)$ & $30.7(9)$ & $22.9(8)$ & $3.2(7)$ & $15.4(7)$ & $7.4(8)$ \\
$\mathrm{N} 1$ & $17.8(9)$ & $23.4(9)$ & $15.8(9)$ & $-0.6(6)$ & $4.4(7)$ & $-0.8(6)$ \\
$\mathrm{C} 1$ & $19.6(11)$ & $29.3(11)$ & $20.9(11)$ & $-0.2(9)$ & $8.1(9)$ & $4.8(9)$ \\
$\mathrm{C} 2$ & $25.0(11)$ & $26.5(11)$ & $21.0(10)$ & $-4.0(9)$ & $6.5(8)$ & $4.7(9)$ \\
\hline
\end{tabular}


Table 3. Cont

\begin{tabular}{ccccccc}
\hline \multicolumn{7}{c}{ Compound (2) } \\
\hline Atom & $\mathbf{U}_{\mathbf{1 1}}$ & $\mathbf{U}_{\mathbf{2 2}}$ & $\mathbf{U}_{\mathbf{3 3}}$ & $\mathbf{U}_{\mathbf{2 3}}$ & $\mathbf{U}_{\mathbf{1 3}}$ & $\mathbf{U}_{\mathbf{1 2}}$ \\
\hline $\mathrm{U} 1$ & $9.63(19)$ & $6.15(18)$ & $4.72(18)$ & $-0.19(13)$ & $0.91(13)$ & $-0.39(13)$ \\
$\mathrm{U} 2$ & $9.57(19)$ & $14.7(2)$ & $5.37(18)$ & $-0.62(14)$ & $1.35(13)$ & $-0.71(14)$ \\
Cs1 & $15.2(5)$ & $44.4(7)$ & $20.7(5)$ & $2.6(5)$ & $-0.3(4)$ & $-1.5(5)$ \\
Cs2 & $57.2(9)$ & $16.7(5)$ & $22.6(6)$ & 0 & $-8.4(6)$ & 0 \\
P1 & $19.1(14)$ & $7.5(12)$ & $9.3(13)$ & $0.0(10)$ & $1.6(11)$ & $1.1(10)$ \\
P2 & $12.5(14)$ & $28.0(16)$ & $7.5(13)$ & $-2.7(12)$ & $0.2(10)$ & $-0.7(12)$ \\
P3 & $7.7(12)$ & $11.4(12)$ & $5.4(12)$ & $-0.1(9)$ & $1.0(9)$ & $0.0(9)$ \\
O1 & $25(5)$ & $10(4)$ & $14(4)$ & $2(3)$ & $4(3)$ & $0(3)$ \\
O2 & $16(4)$ & $10(4)$ & $10(4)$ & $1(3)$ & $-4(3)$ & $5(3)$ \\
O3 & $16(4)$ & $12(4)$ & $9(4)$ & $0(3)$ & $0(3)$ & $-2(3)$ \\
O4 & $11(4)$ & $57(7)$ & $13(4)$ & $2(4)$ & $2(3)$ & $-12(4)$ \\
O5 & $13(4)$ & $20(4)$ & $12(4)$ & $-2(3)$ & $4(3)$ & $-2(3)$ \\
O6 & $14(4)$ & $23(4)$ & $18(4)$ & $-2(4)$ & $5(3)$ & $0(3)$ \\
O7 & $13(4)$ & $20(4)$ & $10(4)$ & $-2(3)$ & $1(3)$ & $-4(3)$ \\
O8 & $17(4)$ & $27(5)$ & $5(3)$ & $1(3)$ & $3(3)$ & $-8(4)$ \\
O9 & $22(4)$ & $16(4)$ & $12(4)$ & $-3(3)$ & $1(3)$ & $8(3)$ \\
O10 & $27(4)$ & $6(3)$ & $10(4)$ & $-5(3)$ & $0(3)$ & $5(3)$ \\
O11 & $13(4)$ & $19(4)$ & $19(4)$ & $-2(3)$ & $7(3)$ & $-3(3)$ \\
O12 & $13(4)$ & $13(4)$ & $11(4)$ & $4(3)$ & $1(3)$ & $-1(3)$ \\
O13 & $40(6)$ & $13(4)$ & $16(4)$ & $1(3)$ & $8(4)$ & $3(4)$ \\
O14 & $21(4)$ & $24(5)$ & $12(4)$ & $-5(3)$ & $-1(3)$ & $8(4)$ \\
N1 & $29(6)$ & $34(7)$ & $20(6)$ & $4(5)$ & $0(5)$ & $-6(5)$ \\
N2 & $29(6)$ & $20(5)$ & $21(6)$ & $3(4)$ & $-2(5)$ & $4(5)$ \\
C1 & $4(4)$ & $11(5)$ & $18(5)$ & $2(4)$ & $2(4)$ & $-2(4)$ \\
C2 & $22(6)$ & $14(5)$ & $13(5)$ & $-7(4)$ & $10(4)$ & $-5(5)$ \\
C3 & $11(5)$ & $12(5)$ & $10(5)$ & $1(4)$ & $4(4)$ & $-1(4)$ \\
C4 & $12(5)$ & $18(6)$ & $13(5)$ & $-3(4)$ & $5(4)$ & $-2(4)$ \\
\hline & & & & & & \\
\hline
\end{tabular}

Table 4. Selected Bond Lengths for (1) and (2).

\begin{tabular}{|c|c|c|c|c|c|}
\hline \multicolumn{6}{|c|}{ Compound (1) } \\
\hline Atom & Atom & Length/Å & Atom & Atom & Length/Å \\
\hline U1 & $\mathrm{O} 1^{1}$ & $2.265(2)$ & P1 & O1 & $1.529(2)$ \\
\hline U1 & $\mathrm{O} 1$ & $2.265(2)$ & P1 & $\mathrm{O} 2$ & $1.504(2)$ \\
\hline U1 & $\mathrm{O} 3^{2}$ & $2.283(2)$ & $\mathrm{P} 1$ & $\mathrm{O} 3$ & $1.520(2)$ \\
\hline U1 & $\mathrm{O} 3^{3}$ & $2.283(2)$ & P1 & $\mathrm{H} 1$ & $1.44(4)$ \\
\hline U1 & $\mathrm{O} 4^{1}$ & $1.785(2)$ & N1 & $\mathrm{C} 1$ & $1.490(3)$ \\
\hline \multirow[t]{2}{*}{ U1 } & $\mathrm{O} 4$ & $1.785(2)$ & N1 & $\mathrm{C} 2$ & $1.489(3)$ \\
\hline & & & $\mathrm{C} 1$ & $\mathrm{C} 2^{4}$ & $1.508(3)$ \\
\hline \multicolumn{6}{|c|}{ Compound (2) } \\
\hline Atom & Atom & Length/Å & Atom & Atom & Length/Å \\
\hline U1 & $\mathrm{O} 1$ & $2.324(8)$ & $\mathrm{P} 1$ & $\mathrm{H} 1$ & $1.48(5)$ \\
\hline U1 & $\mathrm{O} 2^{5}$ & $2.357(8)$ & $\mathrm{P} 2$ & $\mathrm{O} 4$ & $1.509(10)$ \\
\hline U1 & $\mathrm{O} 3^{6}$ & $2.335(8)$ & P2 & O5 & $1.522(9)$ \\
\hline U1 & O9 & $2.494(9)$ & $\mathrm{P} 2$ & O6 & $1.527(9)$ \\
\hline U1 & $\mathrm{O} 10$ & $2.439(8)$ & $\mathrm{P} 2$ & $\mathrm{H} 2$ & $1.54(5)$ \\
\hline U1 & O11 & $1.796(8)$ & P3 & O7 & $1.529(9)$ \\
\hline U1 & $\mathrm{O} 12$ & 1.788(8) & P3 & O8 & $1.551(9)$ \\
\hline U2 & $\mathrm{O} 4$ & $2.315(9)$ & P3 & O9 & $1.548(9)$ \\
\hline $\mathrm{U} 2$ & $\mathrm{O} 5^{7}$ & $2.345(8)$ & P3 & O10 & $1.543(8)$ \\
\hline $\mathrm{U} 2$ & $\mathrm{O} 6^{8}$ & $2.328(9)$ & N1 & $\mathrm{C} 1$ & $1.49(2)$ \\
\hline U2 & $\mathrm{O} 7$ & $2.489(8)$ & N1 & $\mathrm{C} 2$ & $1.52(2)$ \\
\hline $\mathrm{U} 2$ & O8 & $2.473(8)$ & N2 & C3 & $1.49(2)$ \\
\hline $\mathrm{U} 2$ & $\mathrm{O} 13$ & $1.799(9)$ & N2 & $\mathrm{C} 4$ & $1.49(2)$ \\
\hline U2 & O14 & $1.793(9)$ & $\mathrm{C} 1$ & $\mathrm{C} 4$ & $1.49(2)$ \\
\hline P1 & $\mathrm{O} 1$ & $1.530(9)$ & $\mathrm{C} 2$ & C3 & $1.50(2)$ \\
\hline P1 & $\mathrm{O} 2$ & $1.516(9)$ & & & \\
\hline P1 & $\mathrm{O} 3$ & $1.526(8)$ & & & \\
\hline
\end{tabular}

${ }^{1} 1-X, 2-Y, 1-Z ;{ }^{2} 3 / 2-X, 1 / 2+Y, 3 / 2-Z ;{ }^{3}-1 / 2+X, 3 / 2-Y,-1 / 2+Z ;{ }^{4}-X, 1-Y, 1-Z ;{ }^{5} 1+X, 1+Y, Z ;{ }^{6} 1-X, 1 / 2$ $+\mathrm{Y}, 3 / 2-\mathrm{Z} ;{ }^{7} 1-\mathrm{X}, 1-\mathrm{Y}, 1-\mathrm{Z} ;^{8}-1 / 2+\mathrm{X}, 1-\mathrm{Y},+\mathrm{Z}$. 
Table 5. The Stronger of Hydrogen Bonding Interactions from $\mathrm{H}_{2} \mathrm{PZ}^{2+}$ Cations to the Anionic Network for both Compound (1) and (2) are Listed.

\begin{tabular}{cccccc}
\hline \multicolumn{7}{c}{ Compound (1) } \\
\hline D-H & $\mathbf{d}(\mathbf{D}-\mathbf{H})$ & $\mathbf{d}(\mathbf{H} \cdots \mathbf{A})$ & $<$ DHA & $\mathbf{d}(\mathbf{D} \cdots \mathbf{A})$ & $\mathbf{A}$ \\
\hline N1-H1A & 0.890 & 1.887 & 165.67 & 2.758 & O2 \\
N1-H1B & 0.890 & 1.884 & 163.71 & 2.750 & O2 \\
\hline \multicolumn{7}{c}{ Compound (2) } \\
\hline D-H & $\mathbf{d}(\mathbf{D}-\mathbf{H})$ & $\mathbf{d}(\mathbf{H} \cdots \mathbf{A})$ & $<$ DHA & $\mathbf{d}(\mathbf{D} \cdots \mathbf{A})$ & $\mathbf{A}$ \\
\hline C1-H1C & 0.970 & 1.795 & 167.22 & 2.749 & O7 \\
C1-H1D & 0.970 & 1.684 & 171.37 & 2.647 & O8 \\
C3-H3B & 0.970 & 1.852 & 163.72 & 2.796 & O9 \\
C3-H3A & 0.970 & 2.151 & 151.44 & 3.039 & O10 \\
\hline
\end{tabular}

\section{Results and Discussion}

\section{1. $\left[\mathrm{H}_{2} \mathrm{PZ}\right]\left[\mathrm{UO}_{2}\left(\mathrm{HPO}_{3}\right)_{2}\right]$}

The structures presented here were synthesized at low $\mathrm{pH}$ conditions with phosphorous acid, piperazine, cesium carbonate, and uranyl nitrate. The first structure is that of $\left.\left[\mathrm{H}_{2} \mathrm{PZ}_{[}\right] \mathrm{UO}_{2}\left(\mathrm{HPO}_{3}\right)_{2}\right](1)$, as shown in Figure 1. Similar to previous studies, by keeping the reaction time short $(2 \mathrm{~h})$ the redox reaction between phosphorous acid and $\mathrm{UO}_{2}{ }^{2+}$ can be prevented and a uranyl phosphite compound can be isolated. Here the uranyl phosphite sheets of (1) have a rather unique topology amongst uranyl phosphite compounds. Each square bipyramid of U(VI) has four corner-sharing phosphite units in an interrupted autunite-type sheet. Unlike other members of the autunite family, where the tetrahedral anion shares each of its oxygen with square bipyramidal U(VI) polyhedra [32,34], here the proton on the phosphite ligand still points into the sheet but prevents any further bonding. This sheet topology had some similarities to another relative of the autunite family $-\mathrm{K}_{4} \mathrm{UO}_{2}\left(\mathrm{PO}_{4}\right)_{2}$ [43]. Compound (1) appeared as a lower symmetry version of $\mathrm{K}_{4} \mathrm{UO}_{2}\left(\mathrm{PO}_{4}\right)_{2}$ with the hydrogen atoms on the phosphite allowing for the uranyl square bipyramids to be slightly askew instead of aligned in the sheet causing symmetry disruption. Like $\mathrm{K}_{4} \mathrm{UO}_{2}\left(\mathrm{PO}_{4}\right)_{2},(1)$ is anhydrous, but here the sheets were held together by hydrogen bonding from the piperazinium dication. The non-bridging oxygen atoms on the phosphites worked in conjunction with the "yl" oxygen of the uranyl unit to terminate the sheet and provide the source of hydrogen bonding.

The one crystallographically unique uranium exhibited a square bipyramidal geometry, with the terminal $\mathrm{U}=\mathrm{O}$ bonds of the $\mathrm{UO}_{2}{ }^{2+}$ unit having bond lengths of 1.785(2) $\AA$. The average U-O bond length for the four equatorial oxygen atoms was 2.274(2) $\AA$. The one crystallographically unique phosphite ligand contained two types of oxygen atom: Two $\mu_{2}$-bridging oxygen atoms and one terminal oxygen atom. The average P-O bond length in phosphite was $1.518(2) \AA$, with the terminal bond lengths being slightly shorter than that of the bridging oxygen. The bond valence sum (BVS; Table A1) calculations yielded a value of 5.942 for the uranium center, and 4.066 for the phosphorus in phosphite [29,44-46]. These observed bond lengths and BVS values are quite normal for both square bipyramidal uranium(VI) and phosphite.

As stated previously, the one terminal oxygen on the phosphite unit participated in fairly strong hydrogen bonding to the charge balancing piperazinium dications found between the sheets of uranyl phosphite. In the reaction, the stronger phosphorous acid was able to transfer its acidic protons to piperazine to protonate both nitrogen atoms and create the piperazinium dication. This dication has been observed in different organic and inorganic structures [47-52] and has been previously used as an organic templating agent [53]. In the structure of (1), the nitrogen protons (H1A and H1B) on the piperazinium both showed strong hydrogen bonding to $\mathrm{O}(2)$ on the phosphite anion at $\sim 1.89 \AA$ each. Figure 2 depicts these hydrogen bonding interactions. The piperazinium cations hold the 
sheets together via hydrogen bonding, thereby eliminating the need for crystallographic waters of hydration to do the same. Crystals of (1) were quite large, as shown in Figure A1 (inset top) in the Appendix A. When performing BVS calculations on the oxygen atoms, this terminal oxygen does not appear complete unless one considers this strong hydrogen bonding interaction [54], which raises its sum from 1.406 to a more reasonable 1.957. Comparing the piperazinium cation to a recent crystal structure of piperazine [55], showed similar C-C bond distances and some lengthening of the $\mathrm{C}-\mathrm{N}$ bond by $\sim 0.05 \AA$, commonly observed for other piperazinium cations.

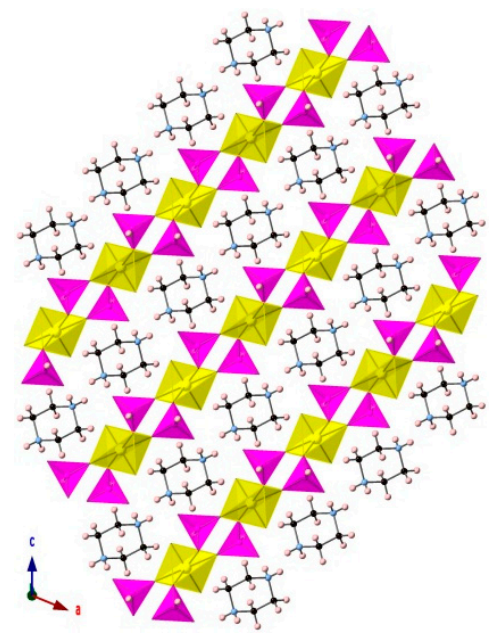

(a)

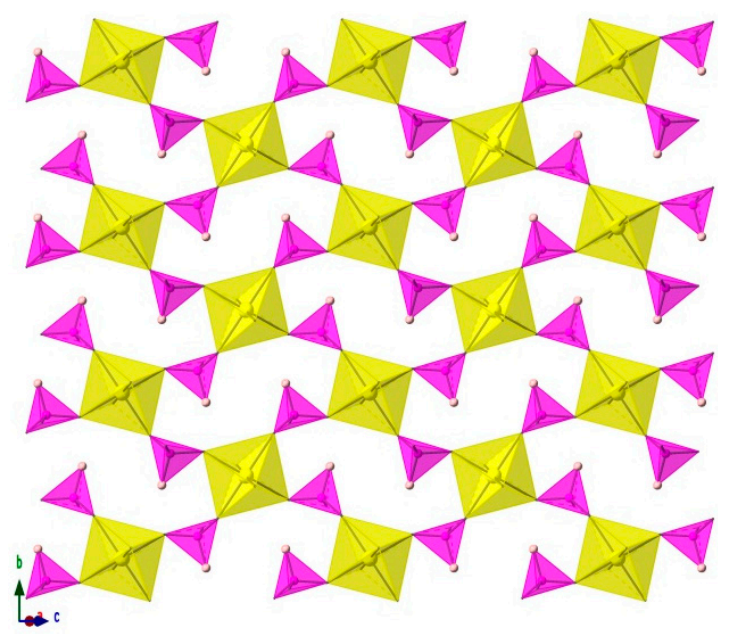

(b)

Figure 1. $\left[\mathrm{H}_{2} \mathrm{PZ}\right]\left[\mathrm{UO}_{2}\left(\mathrm{HPO}_{3}\right)_{2}\right]$ (1): (a) A view of (1) in the ac-plane shows the layers of uranyl phosphite charged balanced by the piperazinium dication; (b) The sheet topology of (1) is shown slightly askew in the [1 $0-1]$ with each square bipyramid of $\mathrm{U}(\mathrm{VI})$ corner sharing to a phosphite ligand through the equatorial oxygen atoms. Here the uranium polyhedra are yellow, phosphites are purple, hydrogen atoms are off-white, carbon atoms are black, and nitrogen atoms are light blue; oxygen atoms are omitted for clarity.

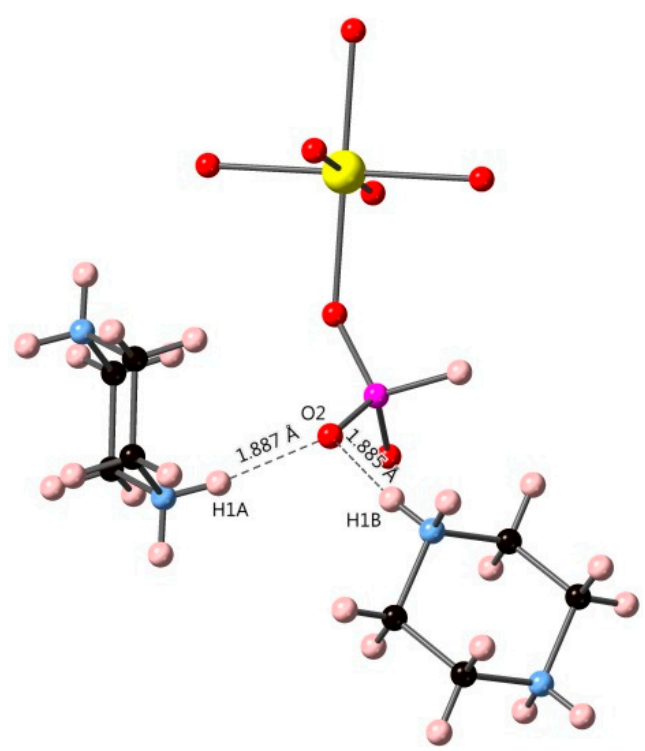

Figure 2. Here the one crystallographically unique phosphite ligand is shown in its coordination to the square bipyramid of uranium, and its hydrogen bonding to the piperazinium dications. $\mathrm{O}(2)$ is the terminal oxygen on phosphite and shows two strong hydrogen bond interactions to H1A and H1B. Color Scheme: U—yellow, phosphorus—purple, oxygen—red, carbon—black, nitrogen—black, and hydrogen-light pink. 
Compound (1) adds to the family of uranyl phosphite compounds. Structural information for uranyl phosphite compounds with monovalent and divalent cations is summarized in Table 6 (Note: Uranyl phosphite compounds with a secondary ligand and/or organically templated with no cation present have not been included for brevity). Included in the table are unit cell and structural comparisons; they are also grouped by structure type. These structure types are visually represented in Figure 3, with Compound (1) listed as structure type (a). Structure types (b)-(f) are sheet topologies with either $\mathrm{K}^{+}, \mathrm{Rb}^{+}, \mathrm{Cs}^{+}, \mathrm{Tl}^{+}$, or $\mathrm{Ca}^{2+}$ charge balancing the layers. Structure types $(\mathrm{g})$ and $(\mathrm{h})$ are both $1 \mathrm{D}$ chains of uranyl phosphite with $\mathrm{Sr}^{2+}$ and $\mathrm{Ba}^{2+}$, respectively, which feature either corner- or edge-sharing between uranyl polyhedra.

Topology types (b)-(e) are 2D uranyl phosphite sheet topologies with monovalent cations, where the equatorial vertex of the uranyl polyhedra connects to a phosphite ligand via a $\mu_{2}$-bridging oxygen. Structure type (e) also contained uranyl polyhedra with a terminal oxygen atom in the equatorial plane. While structure types (b), (d), and (e) each contained only pentagonal bipyramidal $\mathrm{U}(\mathrm{VI})$, structure type (c) had both square and pentagonal bipyramidal $\mathrm{U}(\mathrm{VI})$. In terms of the phosphite ligands, structure types (c) and (e) contained phosphite ligands that only had $\mu_{2}$-bridging oxygen atoms; whereas in (b) and (d), the phosphites contained both $\mu_{2}$-bridging oxygen atoms and terminal oxygen atoms (please note that the terminal $\mathrm{P}-\mathrm{O}$ bond distances in $\mathrm{RbUH}_{2} \mathrm{PO}_{3}, \mathrm{CsUH}_{2} \mathrm{PO}_{3}$, and $\mathrm{TlUH}_{2} \mathrm{PO}_{3}$ in the table appear to be longer than the other terminal $\mathrm{P}-\mathrm{O}$ bonds, as they are protonated).

When looking at the divalent cations, we began to see divergence in the sheet topology starting with $\mathrm{Ca}^{2+}$. Here the calcium cations resided in open pockets of the sheet, which constrained the phosphite ligand and forced an edge-sharing interaction between the uranyl polyhedra and the phosphite ligands. The disorder observed in this $\mathrm{Ca}^{2+}$ cation position and its structure type were discussed in the original work [56]. Moving down the alkaline earth metals to $\mathrm{Sr}^{2+}$ and $\mathrm{Ba}^{2+}$ yielded 1D chain structure types $(\mathrm{g})$ and $(\mathrm{h})$. Chain $(\mathrm{g})$ contained repeating edge-sharing dimers of pentagonal bipyramids of uranium with both corner- and edge-sharing phosphite ligands. These phosphite ligands contained both $\mu_{2}$-bridging and terminal oxygen atom types. Chain (h) had repeating corner-sharing dimers of uranyl pentagonal bipyramids, with an unusually constrained phosphite ligand wedged into the dimer. This odd phosphite coordination, where it was edge-sharing to two different uranyl polyhedra, yielded a unique $\mu_{3}$-bridging phosphite oxygen atom.

Lastly, Compound (1) was different in that it had a dication (piperazinium) balancing the charge, but it contained a sheet topology more similar to that of the monovalent cations. This (a) structure type, contained only square bipyramids of uranium(VI) with each equatorial oxygen bridges to a different phosphite ligand. These phosphites contained both terminal and $\mu_{2}$-briding oxygen types. It is possible that the more flexible nature of the piperazinium, as compared to the larger alkaline earth cations, allowed for sheet topology to form in a slightly altered autunite-type sheet. In general, for the listed compounds, the axial $\mathrm{U}=\mathrm{O}$ bond lengths and the equatorial $\mathrm{U}-\mathrm{O}$ bond lengths fell very much in-line with other uranyl polyhedra of either square or pentagonal bipyramidal geometries, and the $\mathrm{P}-\mathrm{O}$ bond lengths observed in the phosphite ligands were quite common distances for bound phosphite ligands. 
Table 6. A table of the known uranyl phosphite compounds with different mono- and di-valent cations $[16,18,22,56]$. $\mathrm{K}_{2}\left[\left(\mathrm{UO}_{2}\right)_{2}\left(\mathrm{HPO}_{3}\right)_{3}\right] \cdot 2 \mathrm{H}_{2} \mathrm{O}$ $\left.\left(\mathrm{KUPO}_{3}\right), \mathrm{Rb}_{2}\left[\left(\mathrm{UO}_{2}\right)_{2}\left(\mathrm{HPO}_{3}\right)_{3}\right]\left(\mathrm{RbUPO}_{3}\right), \mathrm{Rb}_{2}\left[\left(\mathrm{UO}_{2}\right)_{2}\left(\mathrm{HPO}_{3}\right)_{3}\right]\left(\mathrm{RbUPO}_{3}\right), \mathrm{Cs}_{2}\left[\left(\mathrm{UO}_{2}\right)_{2}\left(\mathrm{HPO}_{3}\right)_{3}\right] \cdot \mathrm{H}_{2} \mathrm{O}\left(\mathrm{CsUPO}_{3}\right), \mathrm{Rb}_{3} \mathrm{UO}_{2}\left(\mathrm{HPO}_{3}\right)\left(\mathrm{H}_{2} \mathrm{PO}_{3}\right)\right] \cdot 3 \mathrm{H}_{2} \mathrm{O}\left(\mathrm{RbUH}_{2} \mathrm{PO}_{3}\right)$, $\mathrm{Cs}_{2}\left[\mathrm{UO}_{2}\left(\mathrm{HPO}_{3}\right)\left(\mathrm{H}_{2} \mathrm{PO}_{3}\right)\right]_{2}\left(\mathrm{CsUH}_{2} \mathrm{PO}_{3}\right), \mathrm{Tl}_{2}\left[\left(\mathrm{UO}_{2}\right)_{2}\left(\mathrm{HPO}_{3}\right)_{3}\right] \cdot \mathrm{H}_{2} \mathrm{O}\left(\mathrm{TlUH}_{2} \mathrm{PO}_{3}\right), \mathrm{Tl}_{6}\left[\left(\mathrm{UO}_{2}\right)_{5}\left(\mathrm{H}_{2} \mathrm{O}\right)\left(\mathrm{HPO}_{3}\right)_{8}\right] \cdot 2 \mathrm{H}_{2} \mathrm{O}\left(\mathrm{TlUPO}_{3}\right), \mathrm{Tl}_{2}\left[\left(\mathrm{UO}_{2}\right)\left(\mathrm{HPO}_{3}\right)\left(\mathrm{H}_{2} \mathrm{PO}_{3}\right)\right]_{2}\left(\mathrm{TlUPO}_{3}-2\right)$, $\left[\mathrm{Ca}_{1.81}\left(\mathrm{UO}_{2}\right)_{0.19}\right]\left[\left(\mathrm{UO}_{2}\right)_{2}\left(\mathrm{HPO}_{3}\right)_{4}\right] \cdot 5 \mathrm{H}_{2} \mathrm{O}\left(\mathrm{CaUPO}_{3}\right), \operatorname{Sr}\left[\left(\mathrm{UO}_{2}\right)\left(\mathrm{HPO}_{3}\right)_{2}\right] \cdot 2 \mathrm{H}_{2} \mathrm{O}\left(\mathrm{SrUPO}_{3}\right), \mathrm{Ba}_{2}\left[\left(\mathrm{UO}_{2}\right)_{2}\left(\mathrm{HPO}_{3}\right)_{4}\right] \cdot 5 \mathrm{H}_{2} \mathrm{O}\left(\mathrm{BaUPO}_{3}\right)$, and Compound $(1)$. Here the vertical double line signifies the break from monovalent to divalent cations.

\begin{tabular}{|c|c|c|c|c|c|c|c|c|c|c|c|c|}
\hline Compound & $\mathrm{KUPO}_{3}$ & $\mathrm{RbUPO}_{3}$ & $\mathrm{CsUPO}_{3}$ & $\mathrm{TlUPO}_{3}$ & $\mathrm{RbUH}_{2} \mathrm{PO}_{3}$ & $\mathrm{CsUH}_{2} \mathrm{PO}_{3}$ & $\mathrm{TlUH}_{2} \mathrm{PO}_{3}$ & $\mathrm{TlUPO}_{3}-2$ & $\mathrm{CaUPO}_{3}$ & $\mathrm{SrUPO}_{3}$ & $\mathrm{BaUPO}_{3}$ & (1) \\
\hline Structure Type & (b) & (c) & (c) & (c) & (c) & (d) & (d) & (e) & (f) & (g) & (h) & (a) \\
\hline$a$ & $7.598(3)$ & 11.1654(2) & $10.7049(2)$ & 11.1774(2) & $8.589(3)$ & $7.975(1)$ & $6.8795(3)$ & 14.705(2) & $22.8646(15)$ & $7.746(2)$ & 10.5731(5) & $8.3711(2)$ \\
\hline$b$ & $6.938(1)$ & $11.3309(2)$ & 11.8511(2) & $11.4215(2)$ & $10.275(1)$ & $10.564(2)$ & $9.7980(4)$ & $10.448(1)$ & $6.6182(3)$ & $8.651(2)$ & $16.6827(8)$ & $7.2898(2)$ \\
\hline$c$ & $10.617(4)$ & $12.1573(2)$ & 12.6431(2) & $12.1390(2)$ & $13.230(4)$ & $10.677(2)$ & $13.3598(6)$ & $26.641(3)$ & $7.0309(4)$ & $8.723(2)$ & $13.3432(7)$ & $10.8505(3)$ \\
\hline$\alpha$ & 90 & 90 & 90 & 90 & 90 & 94.147(3) & $83.848(3)$ & 90 & 90 & 98.81(2) & 90 & 90 \\
\hline$\beta$ & 110.84(2) & 109.376(1) & 101.585(1) & 108.907(1) & 106.83(3) & $95.880(3)$ & $79.249(3)$ & $91.203(8)$ & $94.762(4)$ & $108.52(2)$ & $113.273(2)$ & $112.205(3)$ \\
\hline$\gamma$ & 90 & 90 & 90 & 90 & 90 & 90.411(4) & $74.623(3)$ & 90 & 90 & 110.15(2) & 90 & 90 \\
\hline Crystal System & Monoclinic & Monoclinic & Monoclinic & Monoclinic & Monoclinic & Triclinic & Triclinic & Monoclinic & Monoclinic & Triclinic & Monoclinic & Monoclinic \\
\hline Space Group & $\mathrm{P} 2_{1}$ & $\mathrm{P}_{2} / n$ & $\mathrm{P}_{1} / c$ & $\mathrm{P} 2_{1} / n$ & $\mathrm{P}_{1} / n$ & P-1 & P-1 & $\mathrm{P}_{1} / n$ & $\mathrm{C} 2$ & P-1 & $\mathrm{P}_{1} / c$ & $\mathrm{P}_{1} / n$ \\
\hline Network & Sheet & Sheet & Sheet & Sheet & Sheet & Sheet & Sheet & Sheet & Sheet & Chain & Chain & Sheet \\
\hline Uranyl Polyhedra & РBP & $\begin{array}{l}\text { SBP } \\
\text { PBP }\end{array}$ & $\begin{array}{l}\text { SBP } \\
\text { PBP }\end{array}$ & $\begin{array}{c}\text { SB } \\
\text { PBP }\end{array}$ & РВP & PBP & РBP & PBP & РBP & РBP & РВР & SBP \\
\hline $\begin{array}{l}\text { U-U Polyhedra } \\
\text { Interactions }\end{array}$ & $\begin{array}{c}\text { Isolated } \\
\text { Polyhedra } \\
\end{array}$ & $\begin{array}{c}\text { Isolated } \\
\text { Polyhedra } \\
\end{array}$ & $\begin{array}{c}\text { Isolated } \\
\text { Polyhedra } \\
\end{array}$ & $\begin{array}{c}\text { Isolated } \\
\text { Polyhedra }\end{array}$ & $\begin{array}{c}\text { Isolated } \\
\text { Polyhedra } \\
\end{array}$ & $\begin{array}{c}\text { Isolated } \\
\text { Polyhedra }\end{array}$ & $\begin{array}{c}\text { Isolated } \\
\text { Polyhedra }\end{array}$ & $\begin{array}{c}\text { Isolated } \\
\text { Polyhedra }\end{array}$ & $\begin{array}{c}\text { Isolated } \\
\text { Polyhedra }\end{array}$ & $\begin{array}{c}\text { Edge-Sharing } \\
\text { Dimers }\end{array}$ & $\begin{array}{c}\text { Corner-Sharing } \\
\text { Dimers }\end{array}$ & $\begin{array}{c}\text { Isolated } \\
\text { Polyhedra } \\
\end{array}$ \\
\hline $\begin{array}{c}\mathrm{U}=\mathrm{O} \\
\text { Avg. Bond } \\
\text { Length }(\AA)\end{array}$ & 1.79(1) & $\begin{array}{l}1.788(8) \\
1.76(1)\end{array}$ & $\begin{array}{l}1.785(4) \\
1.786(5)\end{array}$ & $\begin{array}{l}1.772(7) \\
1.770(6)\end{array}$ & $1.78(2)$ & $1.786(4)$ & $1.77(1)$ & $1.75(2)$ & $1.767(9)$ & $1.795(7)$ & $1.780(6)$ & $1.785(2)$ \\
\hline $\begin{array}{c}\text { U-O } \\
\begin{array}{l}\text { Avg. Bond Length } \\
(\AA)\end{array} \\
\end{array}$ & $2.37(2)$ & $\begin{array}{l}2.286(4) \\
2.363(8)\end{array}$ & $\begin{array}{l}2.280(4) \\
2.363(5)\end{array}$ & $\begin{array}{l}2.277(7) \\
2.391(8)\end{array}$ & 2.51(1) & $2.363(4)$ & $2.37(1)$ & $2.36(2)$ & $2.393(9)$ & $2.377(6)$ & $2.394(6)$ & $2.274(2)$ \\
\hline $\begin{array}{c}\text { Phosphite } \\
\text { Oxygen }\end{array}$ & $\begin{array}{c}\text { Terminal \& } \\
\text { Bridging }\end{array}$ & $\begin{array}{c}\text { All } \\
\text { Bridging }\end{array}$ & $\begin{array}{c}\text { All } \\
\text { Bridging }\end{array}$ & $\begin{array}{c}\text { All } \\
\text { Bridging }\end{array}$ & $\begin{array}{l}\text { Terminal \& } \\
\text { Bridging }\end{array}$ & $\begin{array}{l}\text { Terminal \& } \\
\text { Bridging }\end{array}$ & $\begin{array}{c}\text { Terminal \& } \\
\text { Bridging }\end{array}$ & $\begin{array}{c}\text { All } \\
\text { Bridging }\end{array}$ & $\begin{array}{l}\text { Terminal \& } \\
\text { Bridging }\end{array}$ & $\begin{array}{l}\text { Terminal \& } \\
\text { Bridging }\end{array}$ & $\begin{array}{l}\text { Terminal \& } \\
\text { Bridging }\end{array}$ & $\begin{array}{c}\text { Terminal \& } \\
\text { Bridging }\end{array}$ \\
\hline $\begin{array}{c}\mathrm{P}-\mathrm{O} \\
\text { Avg. Bond Length } \\
(\AA)\end{array}$ & $\begin{array}{c}\eta-1.46(2) \\
\mu_{2}-1.53(2)\end{array}$ & $\mu_{2}-1.519(8)$ & $\mu_{2}-1.522(5)$ & $\mu_{2}-1.499(7)$ & $\begin{array}{c}\eta-1.57(1) \\
\mu_{2}-1.48(1)\end{array}$ & $\begin{array}{c}\eta-1.578(5) \\
\mu_{2}-1.516(5)\end{array}$ & $\begin{array}{c}\eta-1.56(1) \\
\mu_{2}-1.50(1)\end{array}$ & $\mu_{2}-1.51(2)$ & $\begin{array}{c}\eta-1.53(1) \\
\mu_{2}-1.526(9)\end{array}$ & $\begin{array}{c}\eta-1.490(7) \\
\mu_{2}-1.540(6)\end{array}$ & $\begin{array}{l}\eta-1.511(5) \\
\mu_{2}-1.534(6) \\
\mu_{3}-1.559(5)\end{array}$ & $\begin{array}{c}\eta-1.504(2) \\
\mu_{2}-1.525(2)\end{array}$ \\
\hline $\begin{array}{c}\mathrm{P}-\mathrm{H} \\
\text { Avg. Bond Length } \\
(\AA)\end{array}$ & 1.13 & 1.33 & 1.46 & 1.37 & 1.23 & 1.31 & 1.41 & $\mathrm{~N} / \mathrm{A}$ & $\mathrm{N} / \mathrm{A}$ & 1.49 & 1.24 & 1.44 \\
\hline Reference & [22] & [16] & [16] & [18] & [22] & [16] & [18] & [18] & [56] & [56] & [56] & This Work \\
\hline
\end{tabular}

SBP $=$ Square Bipyramids; PBP $=$ Pentagonal Bipyramids; $\eta=$ terminal oxygen; $\mu_{2}=$ bridging oxygen with two bonds; $\mu_{3}=$ bridging oxygen with three bonds 


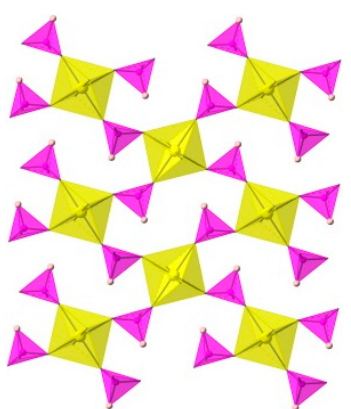

(a)

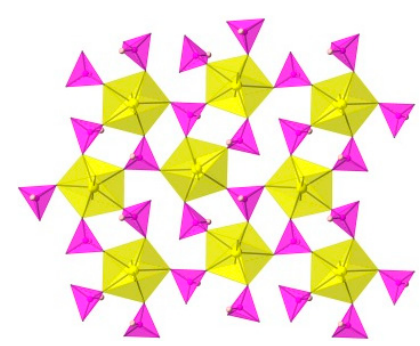

(d)

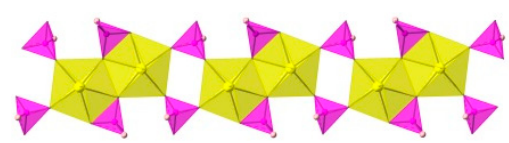

(g)

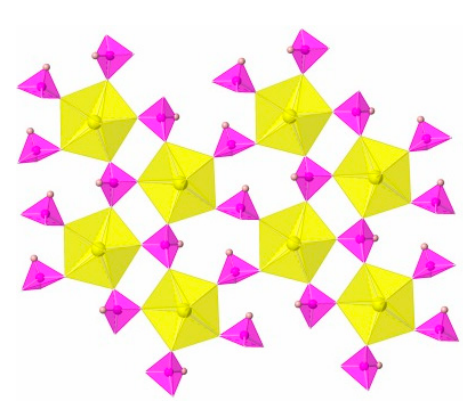

(b)

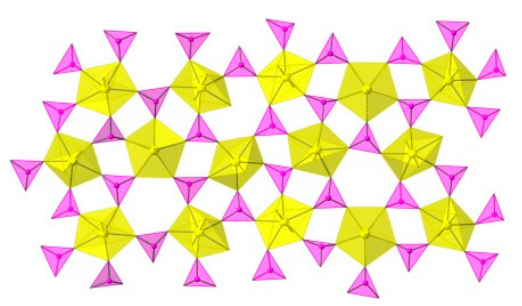

(e)

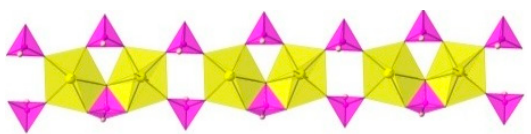

(h)

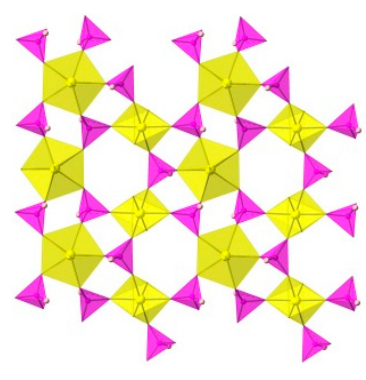

(c)

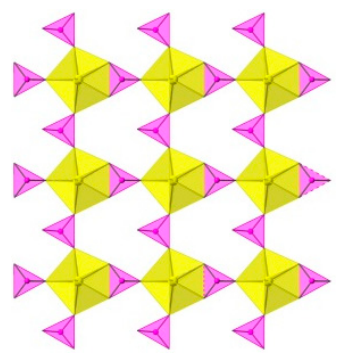

(f)

Figure 3. The eight different uranyl phosphite structure types are shown. The letter label corresponds with the "Structure Type" shown in Table 6. Labels (a)-(f) are all sheet topologies, whereas (g) and (h) are chains. (Please note images (c)-(h) are adapted from their original publication. (c) and (d) adapted with permission from Villa et al. [16]. (e) adapted with permission from Villa et al. [18]. (f)-(h) adapted from Villa et al. [56].

\section{2. $\left[\left(\mathrm{H}_{2} \mathrm{PZ}\right) \mathrm{Cs}\right]\left[\left(\mathrm{UO}_{2}\right)_{2}\left(\mathrm{HPO}_{3}\right)_{2}\left(\mathrm{PO}_{4}\right)\right]$}

When the reaction temperature was raised from $175^{\circ} \mathrm{C}$ to $200{ }^{\circ} \mathrm{C}$ and the time was extended from $2 \mathrm{~h}$ to $6 \mathrm{~h}$, the first signs of oxidation could be observed in the product $\left[\left(\mathrm{H}_{2} \mathrm{PZ}\right) \mathrm{Cs}\right]\left[\left(\mathrm{UO}_{2}\right)_{2}\left(\mathrm{HPO}_{3}\right)_{2}\left(\mathrm{PO}_{4}\right)\right]$ (2). As shown in Figure 4, this product is an open framework structure with both piperazinium and cesium cations in the cavities, which are perpendicular to the ac-plane. Again, the $\mathrm{pH}$ was low enough to cause the piperazine to be protonated in solution, and with the extended heating time, some oxidation of phosphite to phosphate was observed. This 3D framework was made up of isolated pentagonal bipyramids of uranium(VI) linked together via phosphite and phosphate ligands. Both two crystallographically unique uranium polyhedra had three corner-sharing interactions with phosphite, and one edge-sharing interaction with phosphate. These edge-sharing phosphate ligands caused a $180^{\circ}$ rotation in the uranyl polyhedra relative to each other; two of these $\left[\left(\mathrm{UO}_{2}\right)_{2}\left(\mathrm{HPO}_{3}\right)_{2}\left(\mathrm{PO}_{4}\right)\right]$ units then formed the long edge of the cavity. This oblong area measured approximately $18.3 \AA \times 3.2 \AA$, measured between phosphate oxygen and uranyl oxygen, respectively, (Figure 4a), and contains both the piperazinium cations and one of the crystallographically unique cesium cations; the other resides in a small channel between phosphite ligands. 


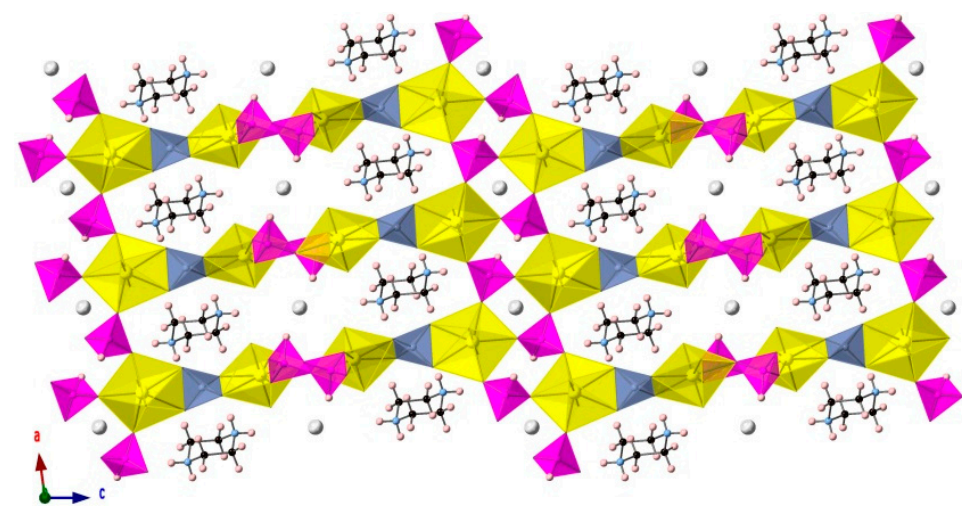

(a)

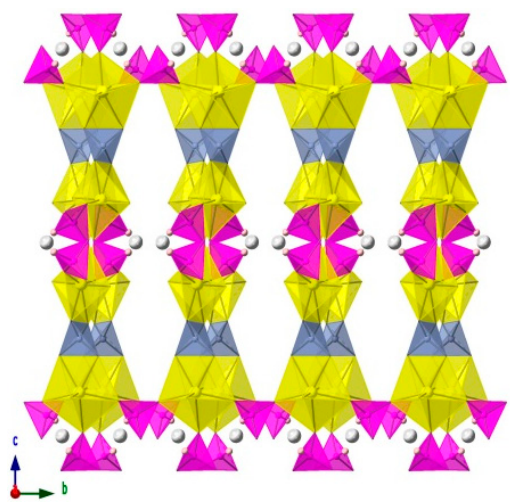

(b)

Figure 4. $\left[\left(\mathrm{H}_{2} \mathrm{PZ}\right) \mathrm{Cs}\right]\left[\left(\mathrm{UO}_{2}\right)_{2}\left(\mathrm{HPO}_{3}\right)_{2}\left(\mathrm{PO}_{4}\right)\right](2)$ : (a) The 3D framework structure of (2) is shown in the ac-plane, where the oblong channels can be observed; (b) These channels are fairly narrow when viewed in the $b c$-plane (the piperazinium cations are omitted for clarity). Color scheme is the same as in Figure 1, save the cesium cations shown in light grey and the phosphate anions shown in blue-grey.

Both U(VI) polyhedra were observed to be pentagonal bipyramidal in geometry. The "yl" bonds in the $\mathrm{UO}_{2}{ }^{2+}$ units had an average bond length of 1.794(9) $\AA$; whereas, the average U-O bond length for the five equatorial oxygen atoms was $2.390(8) \AA$. The two crystallographically unique phosphite ligands now contained only $\mu_{2}$-bridging oxygen atoms. The average $\mathrm{P}-\mathrm{O}$ bond length in the phosphite anions was 1.522(9) $\AA$. By comparison, the average $\mathrm{P}-\mathrm{O}$ bond length in the phosphate ligand was 1.543(9) $\AA$. Again, these U-O bond lengths were normal for pentagonal bipyramidal uranium, phosphite, and phosphate. The BVS calculations yielded a value of 5.918 and 5.898 for the two uranium centers, 3.996 and 4.047 for the phosphorus atoms in the two phosphite ligands, and 4.721 for the phosphorus in the one crystallographically unique phosphate ligand. The value for the phosphate was slightly low, as the $\mathrm{P}-\mathrm{O}$ bond lengths were somewhat longer than expected. This was most likely due to its coordination to the two uranyl units, but these four oxygen atoms also had fairly short hydrogen bonding interactions to the piperazinium cations. As shown in Table 5, each oxygen atom on the phosphate ligand, O7-O10, had fairly short hydrogen bonding interactions to piperazinium cations; interestingly, the phosphate-piperazinium interactions were not through the nitrogen bound hydrogen atoms but through the hydrogen atoms bound to carbon. When these were taken into account, the BVS values for these four oxygen atoms were all close to a value of 2 (Table A2).

Lastly, if these reaction conditions are repeated and the reaction is heated for longer than two days, the only product that was isolated was a cesium uranium(IV) phosphate structure, $\mathrm{Cs}\left[\mathrm{U}\left(\mathrm{PO}_{4}\right)\left(\mathrm{HPO}_{4}\right)_{\mathrm{x}}\left(\mathrm{HPO}_{3}\right)_{1-\mathrm{x}}\right]$, which has been reported previously [16]. This structure represents the complete transition from uranyl phosphite observed in (1) to the uranyl mixed phosphite-phosphate observed in (2) to a completely redox reacted uranium(IV) phosphate. To date, we have not been able to isolate a mixed valent uranium compound with piperazinium cations.

\section{Conclusions}

In this study, we have presented two new uranyl compounds created via hydrothermal syntheses that make use of the piperazinium dication as a templating agent. This cation is formed through in-situ protonation of piperazine molecule by phosphorous acid. By controlling both the starting $\mathrm{pH}$ of the solutions and the reaction time, we were able to successfully synthesize a piperazinium uranyl phosphite compound with a 2D sheet topology and a cesium-piperazinium uranyl phosphite-phosphate compound, which forms a 3D network. As has been previously observed, by keeping the reaction time short, the redox process can be prevented and a uranyl phosphite product can be isolated. The isolation of this compound has added to the uranyl phosphite family and allowed for a discussion of the known uranyl phosphite compounds with monovalent and divalent cations. 
However, when the reaction time is extended, the reaction then yields the mixed a phosphite-phosphate compound. This illustrates the effectiveness of utilizing the in-situ redox technique; moreover, the use of piperazine and phosphorous acid led to the in-situ formation of piperazinium cations to create new, open uranyl networks. From this study, we hope to continue to explore this dynamic process to be able to isolate mixed valent uranium species with piperazinium.

Supplementary Materials: The following are available online at http:/ /www.mdpi.com/2075-163X/8/11/497/ s1, Crystallographic information for (1) and (2). Crystallographic data for the structures in this paper have been deposited with the Cambridge Crystallographic Data Centre: (1) as CCDC 1867196 and (2) as 1867197. Copies of the data can be obtained, free of charge, on application to CCDC, 12 Union Road, Cambridge, CB2 1EZ, UK (fax: +44-(0)1223-336033 or e-mail: despoit@ccdc.cam.ac.uk).

Author Contributions: All authors contributed to the published manuscript. The methodology and conceptualization were conceived by E.M.V. and J.N.C. The experiments were conducted, and the structures were solved by E.M.V. The writing of the document and validation of structures were performed by E.M.V. and J.N.C. Funding was acquired by T.E.A.-S. who also supervised the project.

Funding: We are grateful for previous support for this project provided as part of the Materials Science of Actinides, an Energy Frontier Research Center funded by the U.S. Department of Energy, Office of Science, Office of Basic Energy Sciences under Award Number DE-SC0001089. T.E.A.S. is currently supported as part of the Center for Actinide Science and Technology (CAST), an Energy Frontier Research Center funded by the U.S. Department of Energy, Office of Science, Basic Energy Sciences under Award Number DE-SC0016568.

Conflicts of Interest: The authors declare no conflict of interest.

\section{Appendix A}

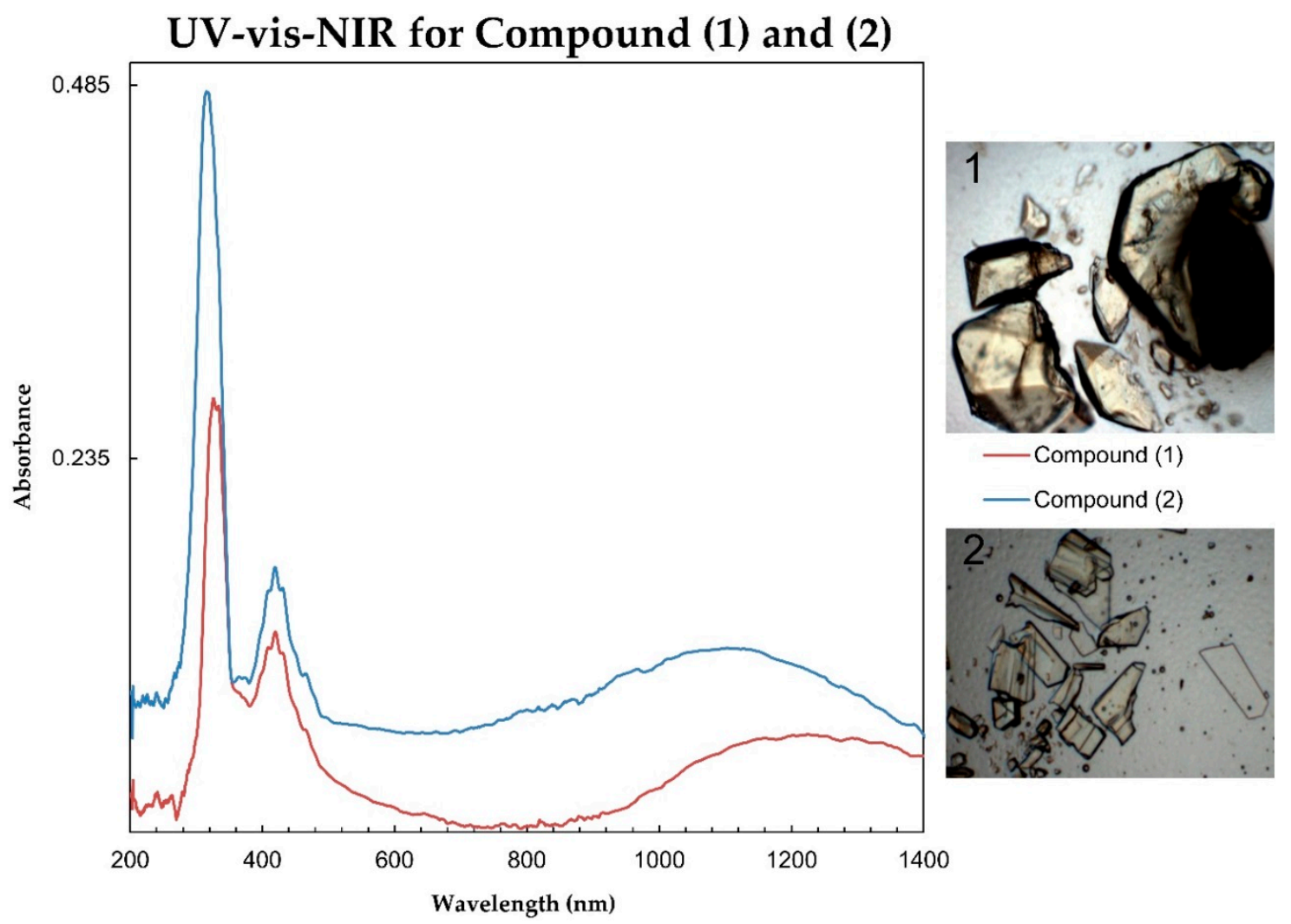

Figure A1. UV-vis-NIR spectra for both Compound (1) and (2) showing the characteristic peaks for $\mathrm{U}(\mathrm{VI})$ between $370-500 \mathrm{~nm}$. Inset photos show the crystalline phases obtained for both compounds. The top photo is of compound (1) and the bottom photo is of compound (2). 
Table A1. Bond Valance Sum (BVS) calculations for Compound (1).

\begin{tabular}{|c|c|c|c|c|c|c|c|c|c|c|c|c|}
\hline & Distance & vu & & Distance & vu & & Distance & vu & & Distance & vu & Total \\
\hline $\mathrm{P}(1)-\mathrm{O}(1)$ & 1.529 & 1.314 & $\mathrm{U}(1)-\mathrm{O}(1)$ & 2.265 & 0.662 & \multirow{4}{*}{$\mathrm{H}(1 \mathrm{~A})-\mathrm{O}(2)$} & \multirow{4}{*}{1.887} & \multirow{4}{*}{0.275} & \multirow{4}{*}{$\mathrm{H}(1 \mathrm{~B})-\mathrm{O}(2)$} & \multirow{4}{*}{1.884} & \multirow{4}{*}{0.277} & 1.976 \\
\hline $\mathrm{P}(1)-\mathrm{O}(2)$ & 1.504 & 1.406 & & & & & & & & & & 1.957 \\
\hline \multirow[t]{3}{*}{$\mathrm{P}(1)-\mathrm{O}(3)$} & 1.52 & 1.346 & $\mathrm{U}(1)-\mathrm{O}(3)$ & 2.283 & 0.640 & & & & & & & 1.986 \\
\hline & & & $\mathrm{U}(1)-\mathrm{O}(4)$ & 1.785 & 1.669 & & & & & & & 1.669 \\
\hline & $\mathrm{P}(1) \mathrm{BVS}$ & 4.066 & & U(1) BVS & 5.942 & & & & & & & \\
\hline
\end{tabular}

Table A2. Bond Valance Sum (BVS) calculations for Compound (2).

\begin{tabular}{|c|c|c|c|c|c|c|c|c|c|c|c|c|}
\hline & Distance & vu & & Distance & vu & & Distance & vu & & Distance & vu & Total \\
\hline $\mathrm{P}(1)-\mathrm{O}(1)$ & 1.53 & 1.310 & $\mathrm{U}(1)-\mathrm{O}(1)$ & 2.324 & 0.591 & $\mathrm{Cs}(1)-\mathrm{O}(1)$ & 3.321 & 0.088 & & & & 1.989 \\
\hline $\mathrm{P}(1)-\mathrm{O}(2)$ & 1.516 & 1.361 & $\mathrm{U}(1)-\mathrm{O}(2)$ & 2.357 & 0.555 & $\mathrm{Cs}(1)-\mathrm{O}(2)$ & 3.269 & 0.101 & & & & 2.016 \\
\hline $\mathrm{P}(1)-\mathrm{O}(3)$ & 1.526 & 1.325 & $\mathrm{U}(1)-\mathrm{O}(3)$ & 2.335 & 0.579 & $\mathrm{Cs}(1)-\mathrm{O}(3)$ & 3.065 & 0.175 & & & & 2.078 \\
\hline $\mathrm{P}(2)-\mathrm{O}(4)$ & 1.509 & 1.387 & $\mathrm{U}(2)-\mathrm{O}(4)$ & 2.315 & 0.601 & & & & & & & 1.988 \\
\hline $\mathrm{P}(2)-\mathrm{O}(5)$ & 1.522 & 1.339 & $\mathrm{U}(2)-\mathrm{O}(5)$ & 2.345 & 0.568 & $\mathrm{Cs}(2)-\mathrm{O}(5)$ & 3.133 & 0.146 & & & & 2.052 \\
\hline $\mathrm{P}(2)-\mathrm{O}(6)$ & 1.527 & 1.321 & $\mathrm{U}(2)-\mathrm{O}(6)$ & 2.328 & 0.586 & $\mathrm{Cs}(2)-\mathrm{O}(6)$ & 3.123 & 0.150 & & & & 2.057 \\
\hline $\mathrm{P}(3)-\mathrm{O}(7)$ & 1.529 & 1.225 & $\mathrm{U}(2)-\mathrm{O}(7)$ & 2.489 & 0.430 & & & & $\mathrm{H}(1 \mathrm{C})-\mathrm{O}(7)$ & 1.795 & 0.352 & 2.007 \\
\hline $\mathrm{P}(3)-\mathrm{O}(8)$ & 1.551 & 1.154 & $\mathrm{U}(2)-\mathrm{O}(8)$ & 2.473 & 0.443 & & & & $\mathrm{H}(1 \mathrm{C})-\mathrm{O}(8)$ & 1.684 & 0.476 & 2.073 \\
\hline $\mathrm{P}(3)-\mathrm{O}(9)$ & 1.548 & 1.163 & $\mathrm{U}(1)-\mathrm{O}(9)$ & 2.494 & 0.426 & & & & $\mathrm{H}(3 \mathrm{~B})-\mathrm{O}(9)$ & 1.852 & 0.302 & 1.891 \\
\hline \multirow[t]{8}{*}{$\mathrm{P}(3)-\mathrm{O}(10)$} & 1.543 & 1.179 & $\mathrm{U}(1)-\mathrm{O}(10)$ & 2.439 & 0.474 & & & & $\mathrm{H}(3 \mathrm{~A})-\mathrm{O}(10)$ & 2.151 & 0.135 & 1.787 \\
\hline & & & $\mathrm{U}(1)-\mathrm{O}(11)$ & 1.796 & 1.634 & $\mathrm{Cs}(1)-\mathrm{O}(11)$ & 3.777 & 0.026 & & & & 1.660 \\
\hline & & & $\mathrm{U}(1)-\mathrm{O}(12)$ & 1.788 & 1.660 & $\mathrm{Cs}(2)-\mathrm{O}(12)$ & 3.426 & 0.066 & & & & 1.726 \\
\hline & & & $\mathrm{U}(2)-\mathrm{O}(13)$ & 1.799 & 1.625 & $\mathrm{Cs}(2)-\mathrm{O}(13)$ & 3.033 & 0.191 & & & & 1.816 \\
\hline & & & $\mathrm{U}(2)-\mathrm{O}(14)$ & 1.793 & 1.644 & $\mathrm{Cs}(2)-\mathrm{O}(14)$ & 3.628 & 0.038 & & & & 1.682 \\
\hline & $\mathrm{P}(1) \mathrm{BVS}$ & 3.996 & & $\mathrm{U}(1) \mathrm{BVS}$ & 5.918 & & & & & & & \\
\hline & P(2) BVS & 4.047 & & U(2) BVS & 5.898 & & & & & & & \\
\hline & P(3) BVS & 4.721 & & & & & & & & & & \\
\hline
\end{tabular}




\section{References}

1. Tabuteau, A.; Pages, M.; Livet, J.; Musikas, C. Monazite-like phases containing Tran-Uranium elements (Neptunium and Plutonium). J. Mater. Sci. Lett. 1988, 7, 1315-1317. [CrossRef]

2. Dacheux, N.; Podor, R.; Chassigneux, B.; Brandel, V.; Genet, M. Actinides immobilization in new matrices based on solid solutions: Th ${ }_{4-\mathrm{x}} \mathrm{M}_{\mathrm{x}}{ }^{\mathrm{IV}}\left(\mathrm{PO}_{4}\right)_{4} \mathrm{P}_{2} \mathrm{O}_{7},\left(\mathrm{M}^{\mathrm{IV}}={ }^{238} \mathrm{U}^{239} \mathrm{Pu}\right)$. J. Alloys Compd. 1998, 271, $236-239$. [CrossRef]

3. Dacheux, N.; Thomas, A.C.; Chassigneux, B.; PichotI, E.; Brandel, V.; Genet, M. Study of $\mathrm{Th}_{4}\left(\mathrm{PO}_{4}\right)_{4} \mathrm{P}_{2} \mathrm{O}_{7}$ and solid solutions with $\mathrm{U}(\mathrm{IV}), \mathrm{Np}(\mathrm{IV})$ and $\mathrm{Pu}(\mathrm{IV})$ : Synthesis, characterization, sintering and leaching tests. MRS Proc. 1999, 556, 85. [CrossRef]

4. Kitaev, D.B.; Volkov, Y.F.; Orlova, A.I. Orthophosphates of tetravalent Ce, Th, U, Np, and Pu with the monazite structure. Radiochemistry 2004, 46, 211-217. [CrossRef]

5. Wellman, D.M.; Mattigod, S.V.; Parker, K.E.; Heald, S.M.; Wang, C.; Fryxell, G.E. Synthesis of organically templated nanoporous Tin(II/IV) phosphate for radionuclide and metal sequestration. Inorg. Chem. 2006, 45, 2382-2384. [CrossRef] [PubMed]

6. Bray, T.H.; Nelson, A.D.; Jin, G.B.; Haire, R.G.; Albrecht-Schmitt, T.E. In situ hydrothermal reduction of Neptunium(VI) as a route to Neptunium(IV) phosphonates. Inorg. Chem. 2007, 46, 10959-10961. [CrossRef] [PubMed]

7. Nelson, A.D.; Bray, T.H.; Zhan, W.; Haire, R.G.; Sayler, T.S.; Albrecht-Schmitt, T.E. Further examples of the failure of surrogates to properly model the structural and hydrothermal chemistry of transuranium elements: Insights provided by uranium and neptunium diphosphonates. Inorg. Chem. 2008, 47, 4945-4951. [CrossRef] [PubMed]

8. Nelson, A.D.; Bray, T.H.; Albrecht-Schmitt, T.E. Capitalizing on differing coordination environments and redox potentials to prepare an ordered heterobimetallic $\mathrm{U}(\mathrm{VI}) / \mathrm{Np}(\mathrm{IV})$ diphosphonate. Angew. Chem. Int. Ed. Engl. 2008, 47, 6252-6254. [CrossRef] [PubMed]

9. Nelson, A.D.; Bray, T.H.; Stanley, F.A.; Albrecht-Schmitt, T.E. Periodic trends in actinide phosphonates: Divergence and convergence between thorium, uranium, neptunium, and plutonium systems. Inorg. Chem. 2009, 48, 4530-4535. [CrossRef] [PubMed]

10. Diwu, J.; Nelson, A.D.; Wang, S.; Campana, C.F.; Albrecht-Schmitt, T.E. Comparisons of Pu(IV) and Ce(IV) diphosphonates. Inorg. Chem. 2010, 49, 3337-3342. [CrossRef] [PubMed]

11. Diwu, J.; Wang, S.; Liao, Z.; Burns, P.C.; Albrecht-schmitt, T.E. Cerium(IV), Neptunium(IV), and Plutonium(IV) 1,2-phenylenediphosphonates: Correlations and differences between early transuranium elements and their proposed surrogates. Inorg. Chem. 2010, 49, 10074-10080. [CrossRef] [PubMed]

12. Knope, K.E.; Cahill, C.L. Homometallic $\mathrm{UO}_{2}{ }^{2+}$ diphosphonates assembled under ambient and hydrothermal conditions. Dalton Trans. 2010, 39, 8319-8324. [CrossRef] [PubMed]

13. Chen, L.; Diwu, J.; Gui, D.; Wang, Y.; Weng, Z.; Chai, Z.; Albrecht-Schmitt, T.E.; Wang, S. Systematic Investigation of the in Situ Reduction Process from U(VI) to U(IV) in a Phosphonate System under Mild Solvothermal Conditions. Inorg. Chem. 2017, 56, 6952-6964. [CrossRef] [PubMed]

14. Villa, E.M.; Wang, S.; Alekseev, E.V.; Depmeier, W.; Albrecht-Schmitt, T.E. Facile routes to $\mathrm{Th}^{\mathrm{IV}}$, $\mathrm{U}^{\mathrm{IV}}$, and $\mathrm{Np}^{\mathrm{IV}}$ phosphites and phosphates. Eur. J. Inorg. Chem. 2011, 3749-3754. [CrossRef]

15. Cross, J.N.; Villa, E.M.; Wang, S.; Diwu, J.; Polinski, M.J.; Albrecht-Schmitt, T.E. Syntheses, structures, and spectroscopic properties of plutonium and americium phosphites and the redetermination of the ionic radii of $\mathrm{Pu}(\mathrm{III})$ and $\mathrm{Am}(\mathrm{III})$. Inorg. Chem. 2012, 51, 8419-8424. [CrossRef] [PubMed]

16. Villa, E.M.; Marr, C.J.; Jouffret, L.J.; Alekseev, E.V.; Depmeier, W.; Albrecht-Schmitt, T.E. Systematic evolution from Uranyl(VI) phosphites to Uranium(IV) phosphates. Inorg. Chem. 2012, 51, 6548-6558. [CrossRef] [PubMed]

17. Villa, E.M.; Marr, C.J.; Diwu, J.; Alekseev, E.V.; Depmeier, W.; Albrecht-Schmitt, T.E. From order to disorder and back again: In situ hydrothermal redox reactions of uranium phosphites and phosphates. Inorg. Chem. 2013, 52, 965-973. [CrossRef] [PubMed]

18. Villa, E.M.; Alekseev, E.V.; Depmeier, W.; Albrecht-Schmitt, T.E. Syntheses, structures, and comparisons of Thallium Uranium phosphites, mixed phosphate-phosphites, and phosphate. Cryst. Growth Des. 2013, 13, 1721-1729. [CrossRef]

19. Avduevskaya, K.A.; Ragulina, N.B.; Rozanov, I.A. Basic Uranyl Phosphites. Inorg. Mater. 1981, 17, $834-836$. 
20. Avduevskaya, K.A.; Rozanov, I.A.; Mironova, V.S. Uranium(IV) Phosphites. Inorg. Mater. 1977, 13, $1515-1517$.

21. Avduevskaya, K.A.; Ragulina, N.B.; Rozanov, I.A. Synthesis and Investigation of Mixed Phosphite Uranylates. Izv. Akad. Nauk SSSR Neorg. Mater. 1978, 14, 2078-2084.

22. Mistryukov, V.E.E.; Mikhailov, Y.N. Crystal Structure of Rb(hydrophosphito)(phosphito)dioxouranate(VI) trihydrate and K(bis(phosphito)dioxouranate(VI) dihydrate.pdf. Koord. Khimiya 1985, 11, 1393-1398.

23. Oh, G.N.; Burns, P.C. Solid-state actinide acid phosphites from phosphorous acid melts. J. Solid State Chem. 2014, 215, 50-56. [CrossRef]

24. Gui, D.; Dai, X.; Zheng, T.; Wang, X.; Silver, M.A.; Chen, L.; Zhang, C.; Diwu, J.; Zhou, R.; Chai, Z.; et al. An ultrastable heterobimetallic Uranium(IV)/Vanadium(III) solid compound protected by a redox-active phosphite ligand: Crystal structure, oxidative dissolution, and first-principles simulation. Inorg. Chem. 2018, 57, 903-907. [CrossRef] [PubMed]

25. Doran, M.; Walker, S.M.; O'Hare, D. Synthesis and characterisation of $\left(\mathrm{C}_{4} \mathrm{~N}_{2} \mathrm{H}_{12}\right)\left(\mathrm{UO}_{2}\right)_{2}\left(\mathrm{PO}_{3} \mathrm{H}\right)_{2}$ $\left\{\mathrm{PO}_{2}(\mathrm{OH}) \mathrm{H}_{2}\right.$ : A three dimensionally connected actinide framework. Chem. Commun. 2001, 2, 1988-1989. [CrossRef]

26. Xu, J.; Li, H.; Cao, Y.; Huang, C.; Zhang, H.; Liu, D.; Yang, Q.; Sun, R. Synthesis and characterization of two new organically templated open-framework Uranium phosphites. Chin. J. Struct. Chem. 2006, 25, 1380-1386.

27. Mandal, S.; Chandra, M.; Natarajan, S. Synthesis, structure, and upconversion studies on organically templated uranium phosphites. Inorg. Chem. 2007, 46, 7935-7943. [CrossRef] [PubMed]

28. Felder, J.B.; Smith, M.D.; zur Loye, H.C. Breaking a paradigm: Observation of magnetic order in the purple $\mathrm{U}(\mathrm{IV})$ phosphite: $\mathrm{U}\left(\mathrm{HPO}_{3}\right)_{2}$. Inorg. Chem. 2018, 57, 9851-9858. [CrossRef] [PubMed]

29. Burns, P.C. The crystal chemistry of hexavalent uranium; polyhedron geometries, bond-valence parameters, and polymerization of polyhedra. Can. Miner. 1997, 35, 1551-1570.

30. Burns, P.C. The crystal chemistry of uranium. Rev. Miner. Geochem. 1999, 38, 23-90.

31. Locock, A.J.; Burns, P.C.; Duke, M.J.M.; Flynn, T.M. Monovalent Cations in structures of the meta-autunite group. Can. Mineral. 2004, 42, 973-996. [CrossRef]

32. Burns, P.C. $\mathrm{U}^{6+}$ Minerals and inorganic compounds: Insights into an expanded structural hierarchy of crystal structures. Can. Miner. 2005, 43, 1839-1894. [CrossRef]

33. Burns, P.C. Crystal chemistry of uranium oxocompounds: An overview. In Structural Chemistry of Inorganic Actinide Compounds; Elsevier: Amsterdam, The Netherlands, 2007; pp. 1-30.

34. Locock, A.J. Crystal chemistry of actinide phosphates and arsenates. In Structural Chemistry of Inorganic Actinide Compounds; Elsevier: Amsterdam, The Netherlands, 2007; pp. 217-278.

35. Krivovichev, S.V. Crystal Chemistry of Uranium Oxides and Minerals. In Comprehensive Inorganic Chemistry II; Elsevier: Amsterdam, The Netherlands, 2013; pp. 611-640.

36. Sheldrick, G.M. SHELXT-Integrated space-group and crystal-structure determination. Acta Crystallogr. Sect. A Found. Adv. 2015, 71, 3-8. [CrossRef] [PubMed]

37. Sheldrick, G.M. Crystal structure refinement with SHELXL. Acta Crystallogr. Sect. C Struct. Chem. 2015, 71, 3-8. [CrossRef] [PubMed]

38. Dolomanov, O.V.; Bourhis, L.J.; Gildea, R.J.; Howard, J.A.K.; Puschmann, H. OLEX2: A complete structure solution, refinement and analysis program. J. Appl. Crystallogr. 2009, 42, 339-341. [CrossRef]

39. CrystalMaker, version 9.2.9.48; Software For Technical Computation; CrystalMaker Software Ltd.: Oxfordshire, UK, 2017.

40. Bell, J.T.; Biggers, R.E. The absorption spectrum of the uranyl ion in perchlorate media. J. Mol. Spectrosc. 1965, 18, 247-275. [CrossRef]

41. Burrows, H.D.; Kemp, T.J. The photochemistry of the uranyl ion. Chem. Soc. Rev. 1974, 3, 139. [CrossRef]

42. Rigaku Oxford Diffraction CrysAlis PRO 2015; Software For Technical Computation; Rigaku: Woodlands, TX, USA, 2015.

43. Linde, S.A.; Gorbunova, Y.E.; Lavrov, A.V. Crystal Structure of $\mathrm{K}_{4} \mathrm{UO}_{2}\left(\mathrm{PO}_{4}\right)_{2}$. Russ. J. Inorg. Chem. 1980, 25, 1992-1994.

44. Brown, I.D.; Altermatt, D. Bond-valence parameters obtained from a systematic analysis of the Inorganic Crystal Structure Database. Acta Crystallogr. Sect. B Struct. Sci. 1985, 41, 244-247. [CrossRef]

45. Brese, N.E.; O'Keeffe, M. Bond-valence parameters for solids. Acta Crystallogr. Sect. B Struct. Sci. 1991, 47, 192-197. [CrossRef] 
46. Loub, J. Crystal chemistry of inorganic phosphites. Acta Crystallogr. Sect. B Struct. Sci. 1991, 47, $468-473$. [CrossRef]

47. Vanier, M.; Brisse, F. Structural studies of compounds with aliphatic chains. 7. The structure of piperazinium glutarate and the geometry of the piperazinium cation. Acta Crystallogr. Sect. B Struct. Crystallogr. Cryst. Chem. 1982, 38, 3060-3063. [CrossRef]

48. Kang, J.; Ahn, J.; Shin, H.; Pyo, S.; Yun, H.; Do, J. Crystal structure of tris(piperazinium) hexakis $\left[(\mu 3-\mathrm{oxo})\left(\mu 2\right.\right.$-oxo)-dioxotungsten]tellurate(VI) hexahydrate, $\left[\mathrm{C}_{4} \mathrm{H}_{12} \mathrm{~N}_{2}\right]_{3}\left[\mathrm{TeW}_{6} \mathrm{O}_{24}\right] 6 \mathrm{H}_{2} \mathrm{O}$. Zeitschrift für Krist. New Cryst. Struct. 2011, 226, 129-130. [CrossRef]

49. Marcotrigiano, G.; Menabue, L.; Pellacani, G.C. Tetrahalo- and (mixed-tetrahalo)cuprates of the piperazinium dication. Coordination geometry changes in some CuX42- anions. Inorg. Chem. 1976, 15, 2333-2336. [CrossRef]

50. Havlíček, D.; Plocek, J.; Němec, I.; Gyepes, R.; Mička, Z. The Crystal Structure, Vibrational Spectra, and Thermal Behavior of Piperazinium(2+) Selenate Monohydrate and $N, N^{\prime}$-Dimethylpiperazinium(2+) Selenate Dihydrate. J. Solid State Chem. 2000, 150, 305-315. [CrossRef]

51. Havlíček, D.; Chudoba, V.; Němec, I.; Císařová, I.; Mička, Z. Preparation, crystal structure, vibrational spectra and thermal behaviour of piperazinium(2+) selenite monohydrate and piperazinium(2+) diselenite. J. Mol. Struct. 2002, 606, 101-116. [CrossRef]

52. Moskwa, M.; Bator, G.; Piecha-Bisiorek, A.; Jakubas, R.; Medycki, W.; Ciżman, A.; Baran, J. X-ray structure and investigation of molecular motions by dielectric, vibrational and $1 \mathrm{H}$ NMR methods for two organic-inorganic hybrid piperazinium compounds: $\left(\mathrm{C}_{4} \mathrm{H}_{12} \mathrm{~N}_{2}\right)_{2}\left[\mathrm{Sb}_{2} \mathrm{Cl}_{10}\right] \cdot 2 \mathrm{H}_{2} \mathrm{O}$ and $\left(\mathrm{C}_{4} \mathrm{H}_{12} \mathrm{~N}_{2}\right)_{2}\left[\mathrm{Sb}_{2} \mathrm{Br}_{10}\right] \cdot 2 \mathrm{H}_{2} \mathrm{O}$. Mater. Res. Bull. 2018, 104, 202-211. [CrossRef]

53. Berrocal, T.; Mesa, J.L.; Pizarro, J.L.; Lezama, L.; Bazán, B.; Arriortua, M.I.; Rojo, T. Hydrothermal synthesis, crystal structure, thermal behavior and spectroscopic and magnetic properties of two new organically templated fluoro-vanadyl-hydrogenarsenates: $(\mathrm{R})_{0.5}\left[(\mathrm{VO})\left(\mathrm{HAsO}_{4}\right) \mathrm{F}\right](R$ : Ethylenediammonium and piperazinium). J. Solid State Chem. 2008, 181, 884-894. [CrossRef]

54. Yu, D.; Xue, D.; Ratajczak, H. Microscopic characteristics of hydrogen bonds of hydrated borates. Phys. $B$ Condens. Matter 2006, 371, 170-176. [CrossRef]

55. Parkin, A.; Oswald, I.D.H.; Parsons, S. Structures of piperazine, piperidine and morpholine. Acta Crystallogr. Sect. B Struct. Sci. 2004, 60, 219-227. [CrossRef] [PubMed]

56. Villa, E.M.; Diwu, J.; Alekseev, E.V.; Depmeier, W.; Albrecht-Schmitt, T.E. Structural changes within the alkaline earth uranyl phosphites. Dalton Trans. 2013, 42, 9637-9644. [CrossRef] [PubMed] 